\title{
Economic performance in rural England
}

\author{
Nigel Curry ${ }^{1}$ and Don J. Webber ${ }^{2}$ \\ ${ }^{1}$ Countryside and Community Research Institute, Cheltenham, UK \\ ${ }^{2}$ Department of Economics, University of the West of England, Bristol, UK
}

\begin{abstract}
English economic policy requires different levels of government to pursue incommensurate, urban-centric, objectives. Rural areas are characterised by 'softer' development approaches centring on relocalisation. Measuring rural economic performance is obscured by the simultaneous use of two spatial platforms: the 'city-region' and the 'rural definition'. The characteristics of these spatial platforms for measuring rural economic performance are explored through plant level productivity data. In general, English rural districts are less productive but particularly where they are both lagging and fall outside city regions. The city-region platform makes the rural productivity performance look worse than it really is but since 2000, rural districts have not been charged with pursuing productivity objectives anyway.
\end{abstract}

JEL Classification: R3; O18

Keywords: Rural economic policy; productivity; skills; industrial structure

Acknowledgements: This work contains statistical data from ONS which is Crown copyright and reproduced with the permission of the controller of HMSO and Queen's Printer for Scotland. The use of the ONS statistical data in this work does not imply the endorsement of the ONS in relation to the interpretation or analysis of the statistical data. This work uses research datasets which may not exactly reproduce National Statistics aggregates. Any errors are the authors' responsibility.

Corresponding author: Dr Don J Webber, School of Economics, Bristol Business School, University of the West of England, Bristol, BS16 1QY, UK. Tel: (+44/0) 11732 82741, Fax: (+44/0) 11732 82295; Email: Don.Webber@uwe.ac.uk. 


\section{Introduction}

Local, regional and national governments in England have been charged and/or adopted with the pursuit of different economic goals. These range from the pursuit of social, environmental and economic well-being, through to stimulating productivity. However, in the rural context, up until 2007, the Department for Environment and Rural Affairs (Defra) has sought more singularly to reduce regional economic and productivity disparities by improving the performance of the weakest regions. These different objectives for economic performance at different governmental levels are likely to cause problems in policy interpretation.

Much of the interpretation of rural economic performance depends on the way in which 'rural' is defined. In economic development terms, the English Government Departments have two competing definitions: i) a spectrum that is dependent on population densities across land area (Defra, 2004) and ii) a classification based commuting pattern that define city regions (Department of Communities and Local Government, 2006). Work also has been undertaken to identify those districts which are lagging or peripheral (Annibal and Doyle, 2007).

This paper analyses the spatial structures of rural economies using labour productivity measures. By employing all of the spatial platforms deployed by the English Government in assessing rural economic performance in tandem, the results indicate that rural districts outside of city regions are no less productive than the urban ones, suggesting that remoteness rather than rurality per se is the more significant influence over productivity and that city regions are likely to make these weak districts even weaker. Rural remoteness, however, does influence individual economic sectors outside of city regions. In particular, there is a greater proportion of hotel and catering plants outside of city regions, the more remote the rural district. This is also true of hotel and catering plants within lagging rural districts. 
This paper has the following structure. The next section summarises current territorial economic frameworks and policies for England. It is followed in Section 3 by a discussion of the implications of this framework for rural areas. Section 4 outlines the competing interpretations of the territorial nature of 'rural'. Section 6 presents an empirical analysis of the different interpretations of rural and provides an indication of the drivers of the labour productivity gaps between categories and Section 7 concludes.

\section{Differential spaces of economic performance in economic development in England}

Since the turn of the Millennium, local, regional and national governments in England have been charged with or adopted the pursuit of different economic goals. Part one of the Local Government Act 2000 (Office for Public Sector Information, 2000) required local authorities to pursue economic (and social and environmental) well-being through the production of a community strategy. The Treasury and Office for the Deputy Prime Minister (2003) focussed on the economic part of this well-being requirement, advising that it should be used to pursue economic performance and local prosperity (page 5). The Local Government White Paper (Department of Communities and Local Government (hereafter DCLG), 2006) committed to the development of a single performance framework for local authorities, proposing that they select up to 35 performance targets from a set of 198 indicators (only 33 of which pertain to the local economy, DCLG, 2007) to provide flexibility in determining the nature of wellbeing in their locality. The Commission for Rural Communities (2008) notes that this broadens the scope for interpreting economic performance.

In contrast to the pursuit of well-being at the local authority level, both national and regional economic performance Public Service Agreements (PSA) have been built around measures of productivity: Gross Value Added (GVA) per head, using output, rather than 
income-based measures. Concern here has been both to increase GVA nationally and to reduce regional disparities both of which have been considered to have met with some success (Treasury et al., 2006). In the rural context, up until 2007, the Department for Environment and Rural Affairs (Defra) has sought more singularly to reduce regional disparities by improving the performance of the weakest regions (Courtney et al., 2004) through the PSA 4 target (Defra, 2005). No acknowledgement was made by Defra in the performance requirements of differences between rural and urban local authorities.

In broad terms, national government and the regions were to pursue notions of productivity, and local authorities were to pursue well-being.

By 2007, the Sub-national Review (Treasury et al., 2007) affirmed that local authorities are to ensure that local economic development increases well-being in their localities (p. 23), this time through a sustainable community strategy or, for upper tier and unitary authorities, their Local Area Agreements. Such well-being should reflect the distinctive identity of the area (p. 43), whilst increasing local prosperity. RDAs are to continue the pursuit of growth through GVA productivity measures per head, but now through a single regional strategy, a specific growth objective and a growth focussed framework (page 93). In this context, Defra has now abandoned PSA 4 and indeed any specifically rural PSA targets, and has introduced a second order Departmental Strategic Objective (DSO) to pursue 'strong rural communities' (Defra, 2008a). This is measured in turn by two 'intermediate outcomes' which reflect both the national preoccupation with productivity and the local authority concern with well-being (Defra 2008b). The first is supporting economic growth in rural areas with the lowest levels of performance and the second is to pursue the evidenced needs of rural people and communities through mainstream public policy. 
Whilst the Defra position in the wake of the 2007 Sub-national Review represents a significant departure from its former PSA 4 target, the most significant change occasioned by the Review has been to introduce the primacy of economic planning at the sub-regional scale. This has come about for at least four reasons. Firstly, the way in which individual local authorities have dealt with economic development has been extremely variable with some smaller authorities showing little evidence of attention to this portfolio at all (DCLG,2008a). These problems will be overcome through sub-regional co-operation between authorities.

Secondly, the sub-regional scale is felt to be the scale at which place-specific economic advantages are often present (for example, pools of labour, higher and further education colleges, suppliers and so on), which provide place-specific returns to scale (DCLG, 2008b). Thirdly, the relationship between 'economics' and 'place' needs to be strengthened because 'place' is where productivity drivers come together and where the life chances of individuals are played out (DCLG, 2008c). Finally, currently sub-regional arrangements, where they do exist, are considered to be fragmented, confused, variable and lacking in capacity, accountability and leadership (Treasury et al., 2007).

The Sub-National Review (Treasury et al. 2007) thus proposes the development of sub-regional economic strategies through Multi-Area Agreements (MAAs), first mooted in the Local Government White Paper of 2006 (DCLG, 2006). These will be voluntary at the point of creation but, if local authorities so wish, they may establish statutory sub-regional authorities (DCLG and DBERR, 2007). These functional sub-regional areas are not that easy to define, although the Local Government Association (2007) has attempted this. The LGA work suggests, and the implication in much of the Sub-national Review literature is, that these functional economic areas as sub-regions will cohere around the notion of the cityregion (OECD, 2006). This has significant implications for rural areas. 


\section{The Sub-national Review: implications for rural areas}

The Sub-national Review (Treasury HM et al., 2007) has an overwhelming urban orientation and does not acknowledge the particular characteristics of rural areas at all. Thus, in setting out the context for the review:

$$
\begin{aligned}
& \text { "economic restructuring gives a key role to cities and towns ..... decision-making } \\
& \text { structures therefore need to ensure that cities and towns have the necessary } \\
& \text { flexibility to develop their own economic niches" (paragraph 4.6, page 48). }
\end{aligned}
$$

In developing sub-regional plans, partnerships between the private sector and local authorities will be conducted through Urban Regeneration Companies who will conduct city summits and generate city business cases and eventually develop into City Development Companies (page 25 - authors' italics). In determining functional economic areas at the sub-regional level, "cities and towns are particularly important" (paragraph 4.13, page 49). The model planning framework, too, Multi-area Agreements (MAAs), is based on precedents developed by a number of cities (Page 89) and the first MAAs are to be in place for cities by June 2008 (page 90).

In acknowledging that functional economic areas are to be based around the cityregion, DCLG (2008b) nevertheless recognises that this runs the risk of residualising many rural areas, particularly as some $25 \%$ of rural districts are not in any city-region (SQW and Cambridge Econometrics, 2006). It maintains (DCLG 2008c) that many remoter areas are simply too small to be encompassed by sub-regional economic systems. Smaller rural 
councils and towns, it claims (DCLG, 2008a) are feeling particularly threatened by the city region agenda. SQW and Cambridge Econometrics (2006) also note that the functionality of city-regions appears to be premised primarily on car-based commuting. They question the sustainability of this approach particularly as a number of recent Local Development Frameworks, for example, have backed away from polices of dispersal, favouring instead, polices of urban concentration This focus is an occlusion felt strongly by Defra's 44 the most lagging (in income terms) rural districts in case studies conducted by Annibal and Doyle (2007).

Much of this concern of the residualisation of, particularly remoter, rural areas in spatial economic policy, stems for the particular GVA basis of measuring economic performance. Not surprisingly, Annibal and Doyle's (2007) survey of Defra's 44 most lagging districts, indicates that they themselves favoured a broader approach to measuring such performance. These calls for different performance measures for rural areas are buttressed by research evidence. Keeble and Tyler (1995) in their studies, for example, found rural firms to be overwhelmingly independent, locally owned and locally managed relative to their urban counterparts. There also is evidence that they are both younger and smaller than urban firms (Keeble and Nachum, 2002; Jarvis and Dunham, 2003) and that most rural new firm founders are in-migrants to the area (Mitchell and Clark, 1999; Courtney and Moseley, 2008) rather than, by contrast to urban firms, from with the locality in which the firm was founded.

But non-economic factors also have a role to play in rural firm formation. Most people writing in this area emphasise the importance of the rural environment as a place to live and work. Such 'quality of life' factors were first noted as a locational determinant in America in the 1950s (Greenhut, 1956; Tiebout, 1957). Tiebout (1957) was to describe the smaller return that entrepreneurs were prepared to make at that time, in exchange for living in 
a 'nice community' and accruing 'psychic income'. More recently, such environmental factors have been identified as being both a spur to relocate (North, 1998) and a clear influence on performance (Johnson and Rasker, 1995).

Keeble and Tyler, (1995), too found that more rural firm founders moved into the area before setting up the firm than set up the firm before moving into the area. These moves were dominantly residentially motivated: villages were perceived to be "a pleasant place to live" ( $p$ 985), and such factors are still significant in the new Millennium (Courtney and Moseley, 2008). The motivations for urban locations are quite different, founded more on economic rationales such as productivity measures. In lending support to the influence of these less tangible factors, Courtney et al. (2004) undertook a series of qualitative surveys in 'well performing' and 'poorer performing' district authorities and found a number of factors relating to the environmental and cultural quality of life to be perceived as being significant in determining economic performance.

These quality of life determinants of location can influence performance in a number of ways. Whilst many authors identify a positive influence (Acs and Malecki, 2003, Terluin, 2003), Galloway and Mochrie (2005) found that it could make firms less ambitious and less growth orientated: they could be lifestyle firms, rather than entrepreneurial. The Deakins et al. (2003) study found, for example, that $86 \%$ of their sample of small rural businesses actually did not want growth. Business orientation is inextricably linked to the motivations and ambitions of the business owner (Culkin and Smith, 2000) and these in turn will influence the receptivity to external policy influence (for example in the area of business advice). As Bryden et al. (2000), put it, rural development is something done by people rather than to people.

These softer notions of rural development have captured the imagination of rural communities themselves, in what Slee (2008) has termed 'relocalisation' where local 
comparative economic advantage in a globalising world tends to run counter to a number of conventional notions of economic theory (Bryden et al., 2000). Slee (2008) criticises the whole concept of growth in economic terms from two principal standpoints. Firstly, economic growth has considerable social and economic costs, or negative externalities, associated with it. When these (for example, the loss of natural capital and inequality) are internalised into productivity measures, such as through the Index of Sustainable Economic Welfare (ISEW) (Matthews et al. 2003), GVA gains are not reflected in ISEW gains.

Secondly, there is only a very weak association between growth and happiness. Slee (2008) cites a large body of literature dating back to the 1960s that clearly indicates that after the attainment of a relatively low level of income, increased wealth shows little or no correlation with increased well-being or happiness. He offers (p. 5) some of Layard's (2005) policy exhortations that follow from this if happiness goals are to be pursued: promote active democracy; prioritise mental health more highly; increase home and community security by not encouraging too much geographical mobility; don't promote the search for status; limit dysfunctional advertising; discourage self[-]defeating work through taxation; make secure work and pensions a higher priority; incentivise producers by encouraging high standards rather than offering financial incentives; rather than maximising income, redistribute it to where it will make most difference.

Growth thus yields negative externalities on the one hand and does not increase happiness on the other. In this context, Slee (2008) calls for a relocalisation of work, energy production, food production and the use of leisure time. It is the pursuit of a number these 'non-growth' characteristics that is enjoying increasing popularity amongst rural communities themselves - quintessentially sustainable development goals. Thus, 'bottom up' initiatives such as community land trusts (Countryside Agency, 2005), community finance solutions (Dayson et al., 2008) alternative foods, local foods, farmers markets and the like 
(Winter, 2003) are all naturally adopting Slee's (2008) notions of relocalisation on the ground. Transition towns in particular offer the pursuit of many of Layard's (2005) happiness objectives in a movement that sits outside of public policy but is gaining considerable momentum from the 'community up' (Hopkins, 2008).

Thus, to sit alongside the policy objectives of productivity at the national and regional levels, and the pursuit of well-being at the local authority level, a definable third 'bottom up' movement in the consideration of rural economic performance might also be considered to be the pursuit of happiness. Whilst the policy goals of productivity and well-being can be seen in various policy documents to disadvantage rural areas because of its urban-centric nature, the pursuit of happiness is much closer to the core of rural economic development, driven by rural communities themselves.

The State of the Rural Economy

Claims about the rural economy of England must be considered with some care. The Commission for Rural Communities (2008) boldly suggests that in productivity ${ }^{1}$ terms:

"rural districts have overtaken England's major cities and urban areas outside of the capital as drivers of the national economy in many respects" (CRC, 2008, p. 76)

But in many respects, too, they have not. Whilst business formation, turnover, GVA productivity and employment are growing more quickly in rural than in urban areas (Countryside Agency, 2005) they are growing from a lower base and proportionate increases

\footnotetext{
${ }^{1}$ This is despite the fact that district authorities have been pursuing well-being rather than productivity objectives since 2000.
} 
are not necessarily good indicators of absolute increases in economic performance. Whilst the CRC (2008) notes that GVA growth in the most remote and remote local authority districts (defined in the following section) is higher even than in London, it also notes that absolute GVA levels in both or these categories are lower than the national average.

Similar interpretations are possible for rural incomes. Average household incomes of rural residents are higher than for urban residents and the more remote the area, the higher the income (CRC, 2008). This is not a good measure of the performance of the rural economy however, since many rural residents actually work in urban areas. As the CRC later notes, the lowest wages in England are to be found in sparse areas, and these wage levels are volatile over time. Wages of those working in rural areas are lower than amongst those living in rural areas but working in urban ones.

In short, rural wages are lower than urban wages, but the extent to which this is a problem depends on two factors. Firstly, such wages have to be set against different costs of living in rural areas and secondly, the extent to which people have chosen to live in rural areas for lifestyle reasons, as has been noted above, electing to take a lower rural wage as a result, needs to be considered.

Unemployment, too, is inversely related to rurality: unemployment rates are lowest in the most remote districts and these rates rise consistently across district classifications as they become more urban (Commission for rural Communities, 2008). But this could be explained by rural unemployed people tending to move to more urban areas to find work, exacerbating urban levels whilst lowering rural ones, as much as by the existence of rural job opportunities.

Some $30 \%$ of all businesses are in rural England too, but they are smaller than urban ones, contain much higher levels of self employment, underemployment, seasonal and part time work and deploy lower skills levels, leading to lower wages than in urban businesses 
(Defra, 2005). Despite the headline data, therefore, Defra (2005) considers that rural areas are inherently less productive than urban areas because of their periperality, an issue that is not fully acknowledged in national assessments of GVA productivity. They also have a very narrow economic base with a small number of sectors dominating rural areas (Lowe and Ward, 2007).

\section{Competing interpretations of the territorial nature of 'rural' in English Policy}

Much of the interpretation of rural economic performance of course depends on the way in which 'rural' is defined. In economic development terms, the English Government Departments have two competing definitions. Defra's (2004) current definition of rural has a number of 'degrees' of rurality contained within it. This spectrum is based upon population densities across the land area of. The definition can be employed to interrogate a wide range of different types of data, but importantly the categories used in the definition change according to the degree to which the data that are being used is spatially disaggregated. The default definition is based on data collected at Census Output Area (COA) level and is presented in Figure 1.

\{Figure 1 about here

At this scale of data collection (COA), there are 8 categories in the definition (ranked in order of sparseness in the above diagram): two are urban (and cover all settlements of more than 10,000 in size) and six are rural. These are classified by both type of settlement (town and fringe, village and dispersed) and by what Champion and Shepherd (2006) term their context - sparse or less sparse. 
If data can be used that are at a level that is more disaggregated than the COA (for example at hectare squared or postcode level) it is possible to derive an even more detailed settlement breakdown than this (more than 8 categories). This breakdown remains unstated (Defra 2005a). It is more common, however, that data, and particularly multiple combinations of data, are available at levels that are more aggregated than the COA level. Most commonly here, data are available only at Census Super Output Area (CSOA) or Ward level on the one hand, or at the local authority district level (LAD) on the other. In each of these cases, the definitions of rural and urban/rural change because aggregation does not allow as many categories as the 8-fold default classification above.

If data are used, disaggregated only to CSOA or Ward level the, the 'spectrum' of definitions that can be used for classifying urban/rural drops to 6, four of which are rural (Defra 2005). These are:

1. Non-sparse urban,

2. Sparse urban,

3. Non-sparse town and fringe,

4. Sparse town and fringe,

5. Non-sparse other,

6. Sparse other.

Where local authority districts (LADs) are used as the most disaggregated geographical area for data, the 'spectrum' variable for classifying rural and rural/urban again changes to a six point classification, this time with three rural classifications. The classification using LAD level data thus becomes: 
1. Major Urban

2. Large Urban

3. Other Urban

4. Significant Rural

5. Rural-50

6. Rural-80

Here, Significant Rural (SR) is defined as a LAD with more than the national average of $26 \%$ of the population living in rural settlements (defined in the Defra definition) Rural 50 (R50) is more than $50 \%$ of the rural population living in rural settlements and Rural 80 (R80) is more than $80 \%$ of the population living in rural settlements). Some 178 of the 354 LADs in England fall into one of these rural types. They comprise $36.5 \%$ of the England population (SR, 13.1\%, R50, 11.7\% and R80, 11.7\%). According to the CRC (2008) these three rural local authority categories broadly represent increasing degrees of remoteness and this terminology of 'remoteness' will be used in the remainder of this paper.

The population of rural LADs (17.9 million in 2001) is much higher than those living in rural areas under the COA definition (9.5 million), because many rural LADs have urban areas within them. It is clear from the foregoing that the definition is not a definition per se, but a structure within which definitions can be derived and made flexible according to the nature and scale of available data, particularly where disparate databases are being used. In the assessment of rural economic performance below, LADs are used as the spatial basis of assessment, and the Defra rural definition distribution of LADs is shown in figure 2 below.

\{Figure 2 about here 
Consistent with the Sub-national Review (Treasury et al., 2007) and the Local Government White Paper (DCLG, 2006), however, work also has been undertaken to classify rural LADs by city region. The SQW and Cambridge Econometrics (2006) study classified district authorities in relation to city regions according to commuting patterns to arrive at the classification in Figure 3 below.

\{Figure 3 about here $\}$

Some observations can be made about these two sets of definition. Firstly, some $25 \%$ of districts defined by Defra as SR, R50 or R80 fall outside of a city-region. Under Defra's old PSA 4 productivity target, 44 low productivity rural districts (average incomes in the lowest quartile of local authorities - yellow in the figure 4 below) were prioritised for sponsored Defra intervention as lagging districts.

A further 22 districts were identified as less severely challenged but with a number of low productivity wards (those just above the lowest quartile and in brown in figure 4). Interestingly, the 44 lagging districts are largely coastal or peripheral and cluster into seven areas. In Annibal and Boyle's (2007) survey of these districts, a number were not aware that they were a Defra lagging district at all and some had never heard of the PSA 4 target.

\{Figure 4 about here\}

All of these 44 lagging districts are either not in city-regions at all (55\% of them green in figure 5 below) or are what Annibal and Doyle (2007) term "peripheral" within a city-region (blue in figure 5 below). 
\{Figure 5 about here $\}$

The SQW and Cambridge Econometrics (2006) study suggested that rural areas within city-regions are about $8 \%$ more productive (using both work-based and resident-based income GVA measures) than rural areas outside of city regions. This is only $5 \%$ when skills, occupational structures and other regional factors are taken into account - considered to be a more accurate reflection of the city-region influence per se. Earnings of rural residents within city-regions are about $18 \%$ higher than those outside, but only about $9 \%$ when occupational structure and skills levels are taken into account. Rural areas within two or more city regions perform better than those only in one. Whist these rates have not changed much in the recent past, rural areas within city-regions are expected to grow more successfully than those outside. In terms of policy, whilst rural areas within city regions perform better than those outside, according to SQW and Cambridge Econometrics (2006) they still retain typically rural characteristics such as low wages and low skills.

The remainder of this paper explores the nature of rural differential economic performance across these two territorial platforms of rural (the Defra definition and the city region) as a means both of identifying influences over performance but also as a means of exploring the extent to which variations in rural economic performance can be attributed to the spatial definitions used as much as more substantive economic parameters. 


\section{Business (plant) structure: rural districts, lagging districts and city regions}

In the empirical analysis below, the plant level data held by the Office for National Statistics in the Annual Respondents Database (ARD2) is used, which brings together a wide range of data relating to individual business units (ONS, 2002). This is supplemented with data from the Defra rural area LAD classifications considered above, to allow comparisons of performance both inside and outside of city regions. It is important to note the level at which the data for the ARD2 are collected. This is the level of the plant and there may be more than one plant in a firm. In the analysis, the term 'plant' is therefore used, rather than 'firm' or 'business', as the base economic unit of the analysis.

The complete ARD2 data set includes all firms with greater than 250 employees in England (which are surveyed on an annual basis as a statutory requirement), but only a sample of firms with fewer than 250 employees. Smaller firms are sampled on a random basis (see ONS, 2002, p.2). The ARD2 data omits Standard Industrial Classification (SIC) 100 (agriculture, forestry and fishing) because of the very small size of businesses in this sector, in employment terms, as noted above. This plant level assessment accounts for the numbers of plants within a firm by using the variable llunit, which is the log of the number of plants within the firm establishment. If the firm is a single plant establishment then this is equal to zero. GVA at factor cost per worker is used as the measure of productivity, measured at the plant (and therefore work-based) rather than the place of residence. Data on firm-specific capital stock is obtainable from the ONS and is matched with firm-specific data within the ARD2. Although this is not identical to the Treasury investment productivity driver (CURDs, 2003), it represents the result of past investments and is appropriate in modelling based on the Cobb-Douglas production function. 
Based on the subsample of the ARD2, which is influenced by data attrition due to the inclusion of additional explanatory variables in the empirical analysis below, some idea of the nature of the differences in economic profiles of rural LADs (relative to each other and relative to non-rural LADs) can be observed. Table A presents a comparison of the plant structure of rural LADs inside and outside of city regions using Defra's LAD classification, SR, R50 and R80. The assessment does not include plants in Major Urban (MU), Large Urban (LU) or Other Urban (OU) LADs (which are part of the Defra definition), which also fall both inside and outside of city regions. Of the 174 Rural LADs in England, 43 of them are outside of city regions.

\{Table A about here

Using these classifications, some 1,257 out of a total of 6,124 plants in rural LADs fell outside of city regions altogether - some $20.5 \%$ of all rural plants. Interestingly, this proportion is consistent across the three different types of rural area, R80, R50 and SR: $20.2 \%$ of plants in the most remote LADs (R80) fall outside of city regions, $20.6 \%$ of plants in less remote LADs (R50) fall outside of city regions and $20.8 \%$ of plants in the least remote of the rural LADs (SR) fall outside of city regions. This suggests that rural plants are equally likely to fall outside of a city region (and therefore not have access to the policy benefits that a city region might confer) irrespective of how remote the LAD is in which the plant is situated. Similarly, remoteness per se does not increase the likelihood of a plant falling outside of a city region.

The economic profile of these 'non-city region' LADs can be explored further, again using Table A, by examining plants by SIC from the ARD2, where remoteness does seem to have a more significant role to play. Thus, $26.3 \%$ of all plants in the hotel and catering sector 
fall outside of city regions in R80 LADs, but only $17.6 \%$ of hotels and catering plants in R50 LADs and $22.1 \%$ of such plants in SR LADs fall outside of city regions. Whilst there are significant differences across different rural categories these are not linear by rurality: real estate plants are least likely to fall outside of city regions in R50 LADs. There also appears to be a U-shaped relationship for plants operating in 'other sectors' that fall outside of city regions with a relatively low proportion existing in R50, but high proportions existing in $\mathrm{R} 80$ LADs; the reverse pattern appears for plants in the transport sector

It is also possible to create an economic profile of Defra's lagging districts by the Defra LAD rural definition for different industrial sectors. The number of plants by SIC from our ARD2 sample is shown in table B below. To provide a context for these plant numbers, of the 71 R80 LADs in England, 26 of them are in lagging districts; of the 50 R50 LADs, 13 of them are in lagging districts, and of the 53 SR LADs, 5 of them are in lagging districts.

\{Table B about here

In R80 LADs, more than half of all hotel and catering plants are in lagging districts, despite the fact that only $37 \%$ of R80 LADs are lagging districts. Only in real estate in R80 LADs are there proportionately fewer plants than the proportion of R80 LADs that are lagging districts. This pattern is broadly repeated for R50 LADs, $26 \%$ of which are lagging districts. The proportion of hotel and catering plants in R50 LADs is lower than in R80 LADs however, where only a third of plants are in lagging R50 districts. The number of plants in lagging SR LADs is small, possibly because of the small number of SD lagging districts and their small proportion of all SDR LADs - only 9\%. Whilst these observations could be due to ARD2 sample selection bias or indeed could result from attrition as a result of the 
introduction of extra explanatory variable in later regressions, the results are likely to be reasonably accurate because of the size of the dataset used.

Turning finally to city regions, of the 354 English LADs, 59 are not in a city region. Of these 59, 20 are R80 LADs, 11 are R50 LADs and 12 are SR LADs. The remaining 16 are urban LADs (MU, LU and OU). Of the 44 lagging districts, 23 are not in a city region. These are all rural LADs: of R80 LADs, 13 of 26 lagging districts are not in city regions; of R50 LADs, 7 of the 13 lagging districts are not in city regions and of the SR LADs, 3 of 5 lagging districts are not in city regions. Table $\mathrm{C}$ shows the distribution of plants in the sample across lagging and non lagging districts and across districts inside and outside of city regions.

\{Table $\mathrm{C}$ about here

Labour productivity: rural districts, lagging districts and city regions

In examining work-place labour productivity levels, the data suggest that plants located in all three of the rural LAD categories in the Defra definition are less productive than the average plant in all English areas taken together (Table D, column 1). Plants in the most rural, R80 LADs, are $17 \%$ less productive than the average English plant; R50 LADs are $11.3 \%$ less productive and SR $6.6 \%$ less productive. Here, there is a clear linear relationship between remoteness and labour productivity: plant productivity declines, the more remote the district.

\{Table D about here $\}$

But what factors might explain these differences? The capital stock of the firm, the size of the plant's workforce and the ratio of part time to full time staff do account for some 
of these differences. Once they are taken into account (in column 2 in Table D) the gap in labour productivity of plants in these districts relative to all plants in all English districts falls to the following: R80 LADs are $15.9 \%$ less productive; R50 LADs are 9.3\% less productive and SR $6.5 \%$ less productive. These labour productivity differences also can be explained in part by the industry in which the plant is operating - some LADs appear to be have a much lower level of labour productivity because they have a higher proportion of plants operating in relatively low productivity industries. Once these differences are taken into account, the productivity differences against all LADs taken together again fall (column 3 in Table D): R80 LADs are $13.4 \%$ less productive; R50 LADs are $8.2 \%$ less productive and SR $6.1 \%$ less productive.

Columns 4, 5 and 6 in Table D offer explanations of the causes of the labour productivity differences between plants in these three rural area definitions and the average English plant. Low levels of labour productivity in R80 LADs are caused by smaller enhancing effects of capital stock, workforces that are too small to have achieved economies of scale and larger proportions of part-time employees. R80 LADs would also have higher observable labour productivity levels if they had greater numbers of construction and manufacturing plants; the detracting effect of plants in the hotel and catering sector are not as large in these areas. In R50 LADs the labour productivity differences can be attributed at least in part to the presence of greater proportions of part-time workers. The low levels of labour productivity in SR LADs seems to be due to the smaller enhancing effects of capital stocks and larger proportions of part-time employees. Such areas would also have higher observable levels of labour productivity if there were more plants operating in the construction, wholesale, real estate and manufacturing sectors and, in common with the R80 LADs, the detracting effect of plants in the hotel and catering sector are not as large in these areas. 
The results presented in Table D are for the whole sample of plants across all areas of England. Table E presents the same types of estimation but this time the sample is constrained to include plants only within city regions. Of the 354 English districts, 295 are within city regions. Of these 295, 131 fall into one of the Defra rural classifications (R80, R50 or SR) and the remainder are urban (MU, LU and OU). Of the 59 LADs not in city regions, 43 (R80, R50 or SR) of them are rural and 16 are urban (MU, LU and OU). The same productivity gap patterns are observable in these tables D and E, albeit with slightly smaller magnitudes. This should be expected because the plants that are operating outside of city regions have been excluded in Table $\mathrm{E}$, and these contain plants that tend to have slightly lower levels of labour productivity. Nevertheless, the results are stable.

\{Table E about here

In examining productivity levels in just the R80, R50 and SR LADs that are outside of city regions, however, some interesting differences do emerge. Table D shows that plants in R80 and R50 LADs outside of city regions are no less labour productive, using traditional levels of statistical significance, than non-rural LADs (MU, LU or OU) outside of city regions. This might suggest that it is not rurality per se that has a particular influence on labour productivity, but rather periperality: falling outside a city region. Table $\mathrm{F}$ also indicates that plants in SR LADs outside of city regions are the most productive of all noncity region areas, and this includes non-rural LADs. Table F suggests that this is largely due to a relatively higher proportion of relatively productive wholesale and real estate plants and greater returns to capital stocks in these non-city region SR areas. This evidence suggests that certain kinds of rurality might even have productivity advantages over more urban LADs where urban and rural LADs are equally peripheral. 
\{Table F about here $\}$

Turning now to lagging districts, table $\mathrm{G}$ presents the results of econometric regressions on a sample which is comprised of plants based in lagging districts and R80 LADs. This is done whilst recognising that there are districts which fall into both of these classifications. This assessment seeks to identify whether the labour productivity performance of plants in the 44 lagging rural districts differs from plants located in the 71 R80 LADs. These results suggest that plant performance in labour productivity terms in lagging districts is about $13 \%$ lower than in R80 LADs (column 1), which can be partly explained by a poorer capital stock and a higher proportion of part-time to full-time workers in lagging districts (column 2) as well as different industrial structures (column 3). Column 4 presents the estimates of a cross-section pseudo-Chow test to identify whether these explanatory variables have different effects on lagging districts than in R80 LADs. It appears that real estate plants are less productive and that the detracting effect of employing part-time workers is greater in lagging districts relative to R80 LADs.

\{Table $\mathrm{G}$ about here $\}$

Table $\mathrm{H}$ presents the results of econometric regressions on a sample which is comprised of plants based in lagging districts and R50 LADs, again recognising that there are districts which are part of both of these classifications. This assessment seeks to identify whether the labour productivity performance of plants in the 44 lagging districts differ from plants located in the $50 \mathrm{R} 0$ LADs. These results suggest that plant performance in labour productivity terms in lagging districts is some $13.6 \%$ lower than in the R50 LADs (column 
1), which can be explained by lower levels of capital stock, fewer scale economies, and a lower ratio of full time to part time workers in lagging districts (column 2) as well as different industrial structures (column 3). Column 4 presents the estimates of a cross-section pseudo-Chow test to identify whether these explanatory variables have different effects on lagging districts than in Rural 50 districts. It appears that lagging districts suffer from lower returns to capital stocks and the detracting effect of employing part time workers in lagging districts is greater relative to Rural 80 districts. The lagging districts, however, do appear to have some advantages over the R50 districts in that they have more productive transport sector plants and hotel and catering plants that are less of a drain on the economy (they are less 'unproductive') than in R50 districts.

\{Table $\mathrm{H}$ about here $\}$

Table I replicates Tables $\mathrm{G}$ and $\mathrm{H}$ by investigating the labour productivity gaps between lagging districts and SR LADs. The results suggest that lagging districts appear to have labour productivity levels some $17.6 \%$ below the SR LADs (column 1). Again, this can be explained partly by lower levels of capital stock and a higher ratio of part time to full time workers (column 2) as well as industrial structure (column 3). Column 4 shows that plants in SR LADs are affected by these explanatory variables in the same way as all other districts in the sample, except that they suffer more from having lower capital stocks and less productive wholesale plants

\{Table I about here $\}$ 
Finally, table $\mathbf{J}$ shows that plants within city regions that are not lagging districts have the highest level of labour productivity of the four LAD categories in the table. The lowest labour productivity is to be found in plants not in city regions that are in lagging districts. Table $\mathrm{J}$ also indicates that plants in city regions are statistically significantly more productive than plants located outside of a city region and plants not in lagging districts are statistically significantly more productive than plants located in lagging districts. Further, within city regions, plants located in lagging districts are statistically significantly less productive than plants located in non-lagging districts and outside of city regions, plants located in lagging districts are statistically significantly less productive than plants located in non-lagging districts. All of these results are statistically significant at the $99 \%$ confidence level.

$\{$ Table $\mathrm{J}$ about here $\}$

From these assessments, the persistent deficiencies in the lagging districts in respect of labour productivity, compared to all rural LADs, appear to be lower levels of capital stock and higher levels of part time, relative to full time, employment. Lower levels of real estate plant productivity (relative to R80 LADs) and wholesale plant productivity (relative to SR LADs) are also evident in the lagging districts. The transport and hotel and catering sectors appear to offer relative productivity advantages for the lagging districts, particularly relative to R50 LADs. 


\section{Conclusions}

This analysis suggests that city regions as spatial structures for economic development are likely to accentuate economic disadvantage in many rural districts. Using the yardstick of labour productivity, the 59 districts that fall outside of city regions are in aggregate less productive than those within city regions. And of these, 43 are rural (20 R80 LADs, 11 R50 LADs and 12 SR LADs). Interestingly, the rural districts outside of city regions are no less productive than the urban ones, suggesting that remoteness rather than rurality per se is the more significant influence over productivity. Indeed, some Significant Rural districts outside of city regions are more productive than urban districts outside of city regions. Further, of the 44 lagging rural districts (defined as being low productivity districts), more than half of them fall outside of city regions. This residualisation in economic development terms can only serve to exacerbate the problems of low productivity in these rural districts: city regions are likely to make these weak districts even weaker.

This analysis also shows that, using all of the spatial platforms deployed by the English Government in assessing rural economic performance in tandem, rural remoteness per se does not influence the overall proportion of rural economic activity that falls outside of city regions. Rural remoteness, however, does influence individual economic sectors outside of city regions. In particular, there is a greater proportion of hotel and catering plants outside of city regions, the more remote the rural district. This is also true of hotel and catering plants within lagging rural districts.

This is significant, because hotel and catering is also a sector with low productivity plants. To a degree, therefore the inherent industrial structure makes remoter rural areas less productive, but it also defines these areas as being amongst the most attractive (through the dominance of tourism) and therefore susceptible to economic 'lifestyle' approaches rather 
than just those that necessarily maximise productivity. The significant presence of part-time working in remoter and lagging areas too, reduces their productivity relative to other areas, but the evidence does not indicate whether this is as a result of lack of job opportunities or through lifestyle choices. Again, high part-time employment levels could be an indication of more endogenous, lifestyle economies rather than productivity driven ones.

The differential objectives for economic performance (productivity, well-being and happiness) at different governmental levels are likely to cause problems in policy interpretation. This is exemplified by the Defra notion of a lagging district. They have been characterised as lagging by Defra, because of their low productivity. Yet since 2000, district authorities have been charged not with the pursuit of productivity, but rather, with well-being. It is likely, because of their relative remoteness, that their well-being indicators are orientated more towards 'lifestyle' than productivity ends. In some areas, even, where transition town designations are becoming numerous (49 had been designated in England in the two years to August 2008), such districts, de facto, may be moving towards the pursuit of happiness objectives, through the selection of particular well-being indicators. These lagging districts have been categorised by a parameter that they have failed to achieve, but have not be asked to pursue anyway.

Perhaps in this context there is some purpose in peripheral rural districts (both those that are lagging and that are not in city regions) forming sub-regional partnerships, as mooted in the Sub-national review (Treasury et al., 2007) actually to assert their identity in wellbeing rather than productivity terms - as places to live and work that are 'different' from productivity driven spaces, were 'quality of life' parameters are perhaps higher on their particular agendas. The wide choice of well-being indicators would also allow such subregional partnerships to shape their economic purpose to their own particular ends, possibly 
even aligning it with the relocalisation movement and the increasing range of 'happiness' initiatives outlined earlier in the paper

The panoply of rural spatial categorisations for economic development combined with the range of measures of economic performance, certainly suggests that at least part of the fortunes of rural districts depend on how they are defined and grouped, rather than necessarily what the quality of life is like for those living and working in them. 


\section{References}

Acs, Z. J., AND Malecki, E. J. (2003) Entrepreneurship in Rural America: The Big Picture.'Center for the Study of Rural America, Federal Reserve Bank of Kansas City, Conference Proceedings. April 28 and 29, 2003. Kansas City, Missouri, 21-29.

Annibal I P and Boyle P (2007) Productivity and Place: Economic Performance in Remote Areas. Local Government Analysis and Research. Local Government Association September, London.

Avis J (2003) Rethinking Trust in a performative culture: the case of education. Journal of Education Policy, 18(3) 315 - 332. May-June.

Bryden J, Atterton J, Courtney P, Hart K Munro G Timm A (2000) Differential Economic Performance in Rural Areas, International Conference on European Rural Policy at the Crossroads. University of Aberdeen, Kings College: The Arkleton Centre for Rural Development Research. June 29-July 12000.

Centre of Urban and Regional Development Studies (2003) Regional Productivity - a Review of the Rural

Perspective, final research report to the Rural Economics Unit of the Department of Environment, Food and Rural Affairs, August

Champion T and Shepherd J (2006) Demographic change in rural England in Speakman L and Lowe P (eds)

The ageing countryside: the growing older population of Rural England, Age Concern Books, London.

Commission for Rural Communities. (2006). State of the Countryside Report. Commission for Rural Communities: Cheltenham.

Commission for Rural Communities (2008) State of the Countryside, Commission for Rural Communities: Cheltenham.

Countryside Agency. 2004. The State of the Countryside 2004. Countryside Agency: Cheltenham.

Countryside Agency (2005) Community Land Trusts and sustainable rural communities, the Countrside Agency, March, Cheltenham.

Courtney P., Agarwal S., Errington A., Moseley M. and Rahman, S. (2004) Determinants of Relative Economic Performance of Rural Areas, Final Research Report Prepared for DEFRA, July, University of Plymouth and Countryside and Community Research Unit.

Courtney P and Moseley M (2008) Determinants of Local Economic Performance: experience from rural England, Local Economy, forthcoming. 
Culkin, N. and Smith, D. (2000) An emotional business: a guide to understanding the motivations of small business decision makers, Qualitative Market Research 3(3) 145-157

Dayson K., Paterson B., Salt A. and P. Vik (2008) Lloyds TSB operational sustainability research projectfinal technical report, Community Finance Solutions, University of Salford, February.

Deakins, D., Galloway, L. \& Mochrie, R. (2003) The Use and Effect of ICT on Scotland's Rural Business Community. Research Report for Scottish Economists’ Network

Department for Communities and Local Government (2006) Strong and Prosperous Communities, Local Government White Paper, October, London

Department for Communities and Local Government (2007) The New Performance Framework for Local Authorities and Local Authority Partnerships: Single Set of National Indicators, October, London.

Department of Communities and Local Government (2008a) Review of Economic Assessment and Strategy Activity at the Local and Sub-regional level, DCLG, March.

Department of Communities and Local Government (2008b) Planning and Optimal Geographical Levels for Economic Decision-making - the sub-regional role, DCLG, March

Department of Communities and Local Government (2008c) Why Place Matters and Implications for the role of Central, Regional and Local Government, DCLG, March, Economics Paper 2.

Department of Communities and Local Government and the Department for Business Enterprise and Regulatory Reform (2008) Prosperous Places: Taking Forward the Review of Sub-national Economic Development and Regeneration, DCLG and DBERR, 31 march.

Department for the Environment Food and Rural Affairs (Defra) (2004) Rural Strategy 2004, Department for Environment, Food and Rural Affairs, London

Department for the Environment, Food and Rural Affairs (Defra) (2005) Productivity in rural England. Rural Economics Unit, Defra: London.

Department for the Environment, Food and Rural Affairs (Defra) (2005a) Defra classification of local authority districts and unitary authorities in England: An Introductory Guide, Defra: London, July.

Department for the Environment, Food and Rural Affairs (2006) Addendum to the public service agreement target technical note 2005 - 2008 for PSA4. Defra, London.

Department of the Environment, Food and Rural Affairs (2008a) Comprehensive Spending Review 2007 -

Performance Framework, Defra, London. 
Department of the Environment, Food and Rural Affairs (2008b) Departmental Strategic Outcomes and their Intermediate Indicators, http://www.defra.gov.uk/corporate/busplan/spending-review/pdf/dso-io-indicatorsrevfeb08.pdf

Galloway L and Mochrie R (2005) Entrepreneurial Motivation, Orientation and Realisation in rural Economies, Discussion Paper Series in Management, Herriot Watt University, DP2004-M04, August, ISSN 1741-9255. Greenhut M. L. (1956) Plant Location in Theory and Practice. University of North Carolina Press. Hopkins R (2008) The Transition Handbook: from oil dependency to local resilience, Green Books, Totnes. Jarvis D and Dunham P(2003) Conceptualising the 'competitive' strategies of rural manufacturing SMEs. Tijdschrift voor Economische en Sociale Geografie 94(2), 246-257.

Johnson J D and Rasker R (1995) The role of economic and quality of life values in rural business location Journal of Rural Studies 11. 405 - 416.

Keeble D, Nachum L, 2002, "Why do business service firms cluster? Small consultancies, clustering and decentralization in London and Southern England" Transactions of the Institute of British Geographers, New Series $2767-90$

Keeble D and Tyler P (1995) Enterprising Behaviour and the Urban-Rural Shift Urban Studies, 32(6) 975-997 Layard, R., (2005), Happiness: lessons from a new science, Penguin ; Harmondsworth.

Local Government Association (2007) Prosperous Communities II: Vive La Devolution, LGA, January.

Local Government Association and the Special Interest Group of Municipal Authorities (2005) Spreading the benefits of town and city centre renewal, conference report, LGA, July.

Lowe P and Ward N (2007), Sustainable Rural Economies: Some Lessons from the English Experience Sustainable Development 15, pp 307-317

Matthews, J. Munday M, Roberts A, and Williams A., (2003), An index of sustainable economic welfare for Wales 1990-2000, BRASS Cardiff, a Report for the Countryside Council for Wales, March.

Mitchell S and Clark D. (1999). Business adoption of information and communications technologies in the twotier rural economy: some evidence from the South Midlands. Journal of Rural Studies 15: 447-455.

North, D. (1998), Rural Industrialisation. In: B. Ilbery, ed., The Geography of Rural Change, pp. 161-188. Harlow: Longman.

Office for National Statistics (ONS) (2002) Annual Respondents' Database, ONS, London. Office of Public Sector Information (1998) The Regional Development Agencies Act, 1998, Chapter 7. Office of Public Sector Information (2000) Local Government Act, 2000, Chapter 22. 
Organisation For European Co-Operation And Development (2006) Building A Competitive City-Region: The Case Of Newcastle In The North East, OECD, Paris

Segal Quince Wicksteed \& Cambridge Econometrics (2006) Economic Performance of Rural Areas Inside and Outside of City Regions. Final report to Defra, September.

Slee RW (2008) Sustainable solutions: dreams, dilemmas, dangers, Rural Futures Conference, Rural future,

Dreams, Dilemmas, Dangers, University of Plymouth, UK, April.

Stern N (2007) the economics of climate change. The Stern Review, Cambridge University Press, 2007.

Terluin, I.J. (2003) Differences in economic development in rural regions of advanced countries: An overview and critical analysis of theories, Journal of Rural Studies, 19(3) 327-344.

Tiebout C. M. (1957) Location theory, empirical evidence, and economic evolution, Pap. Reg. Sci. Ass. $3,7446$.

Treasury HM and the Office of the Deputy Prime Minister (2003) Productivity in the UK 4: the local dimension, June

Treasury HM, Department of Trade and Industry and the Department of Communities and Local Government (2006) Regional Economic Performance Progress to date, December.

Treasury HM, Department for Business, Enterprise and Regulatory Reform and Department for Communities and Local Government (2007) Review of sub-national economic development and regeneration PU300, London, July ISBN 978-1-84532-317-2

Ward N (2008) England should embrace its rural economy, the Financial Times, June 5.

Webber DJ, Curry NR and Plumridge A (2008) Rural Business Productivity in England and Wales and the New Definition of Rural, Regional Studies, 42(10)), pp 1 - 15.

Winter, M., (2003), Embeddedness, the new food economy and defensive localism. Journal of Rural Studies 19 pp. 23-32 
Table A: numbers of rural plants by Defra rural definition, within and outside of city regions in England

\begin{tabular}{|c|c|c|c|c|c|c|c|c|c|c|}
\hline & \multicolumn{3}{|c|}{ Rural 80} & \multicolumn{3}{|c|}{ Rural 50} & \multicolumn{3}{|c|}{ Significant Rural } & \multirow{2}{*}{$\begin{array}{c}\begin{array}{c}\text { Totals from rural } 80, \\
\text { rural } 50 \text { and } \\
\text { significant rural }\end{array} \\
\text { Total }\end{array}$} \\
\hline & $\begin{array}{l}\text { City } \\
\text { region } \\
\text { (a) }\end{array}$ & $\begin{array}{l}\text { Not city } \\
\text { region } \\
\text { (b) }\end{array}$ & $\begin{array}{c}\text { Percent } \\
\text { (b) } \\
/(a)+(b)\end{array}$ & $\begin{array}{l}\text { City } \\
\text { region } \\
\text { (c) }\end{array}$ & $\begin{array}{l}\text { Not city } \\
\text { region } \\
\text { (d) }\end{array}$ & $\begin{array}{l}\text { Percent } \\
\text { (d) } \\
/(\mathrm{c})+(\mathrm{d})\end{array}$ & $\begin{array}{l}\text { City } \\
\text { region } \\
\text { (e) }\end{array}$ & $\begin{array}{l}\text { Not city } \\
\text { region } \\
\text { (f) }\end{array}$ & $\begin{array}{l}\text { Percent } \\
\text { (f) } \\
/(\mathrm{e})+(\mathrm{f})\end{array}$ & \\
\hline Construction & 137 & 22 & 13.8 & 128 & 31 & 19.5 & 151 & 40 & 20.1 & 509 \\
\hline $\begin{array}{l}\text { Hotels and catering } \\
\text { sector }\end{array}$ & 365 & 130 & 26.3 & 357 & 76 & 17.6 & 385 & 109 & 22.1 & 1422 \\
\hline Manufacturing & 332 & 77 & 18.8 & 293 & 92 & 23.9 & 307 & 86 & 21.9 & 1187 \\
\hline Real estate & 272 & 49 & 15.3 & 295 & 58 & 16.4 & 364 & 72 & 16.5 & 1110 \\
\hline Transport & 90 & 13 & 12.6 & 87 & 29 & 25.0 & 88 & 23 & 20.7 & 330 \\
\hline Wholesale & 410 & 116 & 22.1 & 367 & 109 & 22.9 & 439 & 125 & 22.2 & 1566 \\
\hline Other sectors & 279 & 87 & 22.7 & 272 & 56 & 17.1 & 287 & 86 & 23.1 & 1067 \\
\hline Total & 1606 & 407 & 20.2 & 1527 & 395 & 20.6 & 1734 & 455 & 20.8 & 6124 \\
\hline
\end{tabular}

Notes: Sample sizes in other tables are much larger than the numbers in this table; this is because this table relates only to the number of plants in local authority classifications "Rural 80", "Rural 50" and "Significant rural" and not the plants included in the sample from urban areas. Source: ONS 
Table B: numbers of plants in the sample by different types of rural district

\begin{tabular}{|c|c|c|c|c|c|c|}
\hline & \multicolumn{2}{|c|}{$\begin{array}{l}\text { LA class } 1 \\
\text { "Rural 80" }\end{array}$} & \multicolumn{2}{|c|}{$\begin{array}{l}\text { LA class } 2 \\
\text { "Rural 50" }\end{array}$} & \multicolumn{2}{|c|}{$\begin{array}{l}\text { LA class } 3 \\
\text { "Significant } \\
\text { Rural" }\end{array}$} \\
\hline & $\begin{array}{l}\text { Not in } \\
\text { lagging } \\
\text { district }\end{array}$ & $\begin{array}{c}\text { In } \\
\text { lagging } \\
\text { district }\end{array}$ & $\begin{array}{l}\text { Not in } \\
\text { lagging } \\
\text { district }\end{array}$ & $\begin{array}{l}\text { In } \\
\text { lagging } \\
\text { district }\end{array}$ & $\begin{array}{l}\text { Not in } \\
\text { lagging } \\
\text { district }\end{array}$ & $\begin{array}{c}\text { In } \\
\text { lagging } \\
\text { district }\end{array}$ \\
\hline Construction & 110 & 49 & 120 & 39 & 182 & $<10$ \\
\hline Wholesale & 373 & 153 & 380 & 96 & 528 & 36 \\
\hline Transport & 76 & 27 & 81 & 35 & 97 & 14 \\
\hline Real estate & 261 & 60 & 298 & 55 & 421 & 15 \\
\hline Manufacturing & 277 & 132 & 289 & 96 & 362 & 31 \\
\hline $\begin{array}{l}\text { Hotels and } \\
\text { catering }\end{array}$ & 81 & 48 & 79 & 26 & 109 & 12 \\
\hline Other sectors & 267 & 99 & 271 & 57 & 353 & 20 \\
\hline
\end{tabular}

Notes: Sample sizes in tables below are much larger than the numbers in this table; this is because this table relates only to the number of plants in "Rural 80", "Rural 50" and "Significant Rural" classifications. Source: ONS 
Table C: numbers of plants in the sample by lagging rural districts and by districts inside and outside of city regions.

\begin{tabular}{|l|c|c|c|}
\hline & $\begin{array}{c}\text { Not a lagging } \\
\text { district }\end{array}$ & $\begin{array}{c}\text { Lagging } \\
\text { district }\end{array}$ & Total \\
\hline City region & 13,883 & 632 & 14,515 \\
\hline Not a city region & 1,252 & 477 & 1,729 \\
\hline Total & 15,135 & 1,109 & 16,244 \\
\hline
\end{tabular}

Source: ONS 
Table D: Labour productivity disparities in Rural 80, Rural 50 and Significant Rural Local Authority Districts, relative to the whole sample

\begin{tabular}{|c|c|c|c|c|c|c|c|c|c|}
\hline & 1 & 2 & 3 & \multicolumn{2}{|c|}{4 (Rural 80) } & \multicolumn{2}{|c|}{5 (Rural 50) } & \multicolumn{2}{|c|}{6 (Significant rural) } \\
\hline$N$ & 16810 & 15691 & 15691 & \multicolumn{2}{|c|}{15691} & \multicolumn{2}{|c|}{15691} & \multicolumn{2}{|c|}{15691} \\
\hline & & & & Standard & Compound & Standard & Compound & Standard & Compound \\
\hline Rural 80 & $\begin{array}{c}-0.170 * * * \\
(0.026)\end{array}$ & $\begin{array}{c}-0.159 * * * \\
(0.023)\end{array}$ & $\begin{array}{c}-0.134 * * * \\
(0.022)\end{array}$ & - & $\begin{array}{l}-0.090 \\
(0.082)\end{array}$ & - & - & - & - \\
\hline Rural 50 & $\begin{array}{c}-0.113 * * * \\
(0.026) \\
\end{array}$ & $\begin{array}{c}-0.093 * * * \\
(0.023) \\
\end{array}$ & $\begin{array}{c}-0.082 * * * \\
(0.022) \\
\end{array}$ & - & - & - & $\begin{array}{l}-0.049 \\
(0.082) \\
\end{array}$ & - & - \\
\hline Significant rural & $\begin{array}{c}-0.066 * * * \\
(0.025) \\
\end{array}$ & $\begin{array}{c}-0.065 * * * \\
(0.022) \\
\end{array}$ & $\begin{array}{c}-0.061 * * * \\
(0.021) \\
\end{array}$ & - & - & - & - & - & $\begin{array}{l}-0.130 \\
(0.081) \\
\end{array}$ \\
\hline $\begin{array}{l}\text { Log (capital stock per } \\
\text { worker) }\end{array}$ & - & $\begin{array}{c}0.265^{* * * *} \\
(0.005)\end{array}$ & $\begin{array}{c}0.300 * * * \\
(0.005)\end{array}$ & $\begin{array}{c}0.306 * * * \\
(0.005)\end{array}$ & $\begin{array}{c}-0.061 * * * \\
(0.016) \\
\end{array}$ & $\begin{array}{c}0.302 * * * \\
(0.005)\end{array}$ & $\begin{array}{l}-0.012 \\
(0.016) \\
\end{array}$ & $\begin{array}{c}0.303 * * * \\
(0.005)\end{array}$ & $\begin{array}{c}-\mathbf{0 . 0 3 0} * * \\
(0.015) \\
\end{array}$ \\
\hline Log (employees) & - & $\begin{array}{l}-0.008^{*} \\
(0.004)\end{array}$ & $\begin{array}{l}-0.007 \\
(0.004)\end{array}$ & $\begin{array}{l}-0.008^{*} \\
(0.005)\end{array}$ & $\begin{array}{l}0.025 * \\
(0.014) \\
\end{array}$ & $\begin{array}{l}-0.006 \\
(0.005)\end{array}$ & $\begin{array}{c}0.015 \\
(0.014)\end{array}$ & $\begin{array}{l}-0.005 \\
(0.005)\end{array}$ & $\begin{array}{c}0.005 \\
(0.013) \\
\end{array}$ \\
\hline $\mathrm{Pt} / \mathrm{ft}$ ratio & - & $\begin{array}{c}-0.011 * * * \\
(0.001)\end{array}$ & $\begin{array}{c}-0.010 * * * \\
(0.001)\end{array}$ & $\begin{array}{c}-0.009 * * * \\
(0.001)\end{array}$ & $\begin{array}{c}-0.015 * * * * \\
(0.003)\end{array}$ & $\begin{array}{c}-0.010^{* * * *} \\
(0.001)\end{array}$ & $\begin{array}{l}-0.008 * \\
(0.004)\end{array}$ & $\begin{array}{c}-0.010 * * * \\
(0.001)\end{array}$ & $\begin{array}{c}-\mathbf{- 0 . 0 4 3} * * * \\
(0.007) \\
\end{array}$ \\
\hline Plants & - & $\begin{array}{c}-0.031 * * * \\
(0.008) \\
\end{array}$ & $\begin{array}{c}-0.032 * * * \\
(0.008) \\
\end{array}$ & $\begin{array}{c}-0.031 * * * \\
(0.008) \\
\end{array}$ & $\begin{array}{l}-0.015 \\
(0.026) \\
\end{array}$ & $\begin{array}{c}-0.029 * * * \\
(0.008)\end{array}$ & $\begin{array}{l}-0.031 \\
(0.026) \\
\end{array}$ & $\begin{array}{c}-0.032 * * * \\
(0.008) \\
\end{array}$ & $\begin{array}{l}-0.003 \\
(0.023) \\
\end{array}$ \\
\hline Construction & - & - & $\begin{array}{c}0.350 * * * \\
(0.030) \\
\end{array}$ & $\begin{array}{c}0.320 * * * \\
(0.032) \\
\end{array}$ & $\begin{array}{r}0.215 * * \\
(0.092) \\
\end{array}$ & $\begin{array}{c}0.346 * * * \\
(0.032)\end{array}$ & $\begin{array}{c}0.031 \\
(0.092) \\
\end{array}$ & $\begin{array}{c}0.319 * * * \\
(0.033) \\
\end{array}$ & $\begin{array}{c}\mathbf{0 . 2 0 3} * * \\
(\mathbf{0 . 0 8 6 )}\end{array}$ \\
\hline Wholesale & - & - & $\begin{array}{c}0.193 * * * \\
(0.022) \\
\end{array}$ & $\begin{array}{c}0.180 * * * \\
(0.023)\end{array}$ & $\begin{array}{l}0.090 \\
(0.067) \\
\end{array}$ & $\begin{array}{c}0.195 * * * \\
(0.023)\end{array}$ & $\begin{array}{l}-0.026 \\
(0.069) \\
\end{array}$ & $\begin{array}{c}0.153 * * * \\
(0.023) \\
\end{array}$ & $\begin{array}{c}0.285 * * * \\
(0.065) \\
\end{array}$ \\
\hline Transport & - & - & $\begin{array}{l}0.076^{* *} \\
(0.033)\end{array}$ & $\begin{array}{c}0.057 \\
(0.035)\end{array}$ & $\begin{array}{c}0.137 \\
(0.105)\end{array}$ & $\begin{array}{c}0.083 * * \\
(0.035)\end{array}$ & $\begin{array}{l}-0.043 \\
(0.102)\end{array}$ & $\begin{array}{c}0.052 \\
(0.035)\end{array}$ & $\begin{array}{c}0.166 \\
(0.103)\end{array}$ \\
\hline Real estate & - & - & $\begin{array}{c}0.375^{* * *} \\
(0.022) \\
\end{array}$ & $\begin{array}{c}0.367 * * * \\
(0.024) \\
\end{array}$ & $\begin{array}{c}0.106 \\
(0.074) \\
\end{array}$ & $\begin{array}{c}0.384 * * * \\
(0.024) \\
\end{array}$ & $\begin{array}{l}-0.014 \\
(0.073) \\
\end{array}$ & $\begin{array}{c}0.354 * * * \\
(0.024) \\
\end{array}$ & $\begin{array}{c}0.221 * * * \\
(0.068) \\
\end{array}$ \\
\hline Manufacturing & - & - & $\begin{array}{c}0.068 * * * \\
(0.023)\end{array}$ & $\begin{array}{l}0.044 * \\
(0.025) \\
\end{array}$ & $\begin{array}{r}\mathbf{0 . 1 5 9} * * \\
(0.070) \\
\end{array}$ & $\begin{array}{c}0.057 * * \\
(0.025) \\
\end{array}$ & $\begin{array}{c}0.052 \\
(0.073) \\
\end{array}$ & $\begin{array}{c}0.021 \\
(0.024) \\
\end{array}$ & $\begin{array}{c}0.299 * * * \\
(0.070)\end{array}$ \\
\hline Hotels and catering & - & - & $\begin{array}{c}-0.807 * * * \\
(0.034)\end{array}$ & $\begin{array}{c}-0.828 * * * \\
(0.037)\end{array}$ & $\begin{array}{l}0.192 * \\
(0.104)\end{array}$ & $\begin{array}{c}-0.808 * * * \\
(0.036)\end{array}$ & $\begin{array}{c}0.025 \\
(0.113) \\
\end{array}$ & $\begin{array}{c}-0.828 * * * \\
(0.037)\end{array}$ & $\begin{array}{c}0.209 * * \\
(0.103)\end{array}$ \\
\hline $\mathrm{R}^{2}$ & 0.003 & 0.195 & 0.260 & \multicolumn{2}{|c|}{0.261} & \multicolumn{2}{|c|}{0.258} & \multicolumn{2}{|c|}{0.261} \\
\hline$F$ statistic & $18.83 * * *$ & $542.53 * * *$ & $422.95 * * *$ & \multicolumn{2}{|c|}{$262.90 * * *$} & \multicolumn{2}{|c|}{$259.50 * * *$} & \multicolumn{2}{|c|}{$263.22 * * *$} \\
\hline $\begin{array}{l}\text { Test for compound } \\
\text { variables deletion }\end{array}$ & - & - & - & \multicolumn{2}{|c|}{$6.05 * * *$} & \multicolumn{2}{|c|}{1.27} & \multicolumn{2}{|c|}{$6.51 * * *$} \\
\hline
\end{tabular}

Source: ONS 
Table E: Labour productivity disparities in Rural 80, Rural 50 and Significant Rural Local Authority Districts within city regions, relative to the whole sample of plants in city regions

\begin{tabular}{|c|c|c|c|c|c|c|c|c|c|}
\hline & 1 & 2 & 3 & \multicolumn{2}{|c|}{4 (Rural 80) } & \multicolumn{2}{|c|}{5 (Rural 50) } & \multicolumn{2}{|c|}{6 (Significant rural) } \\
\hline$N$ & 15081 & 14103 & 14103 & \multicolumn{2}{|c|}{14103} & \multicolumn{2}{|c|}{14103} & \multicolumn{2}{|c|}{14103} \\
\hline & & & & Standard & Compound & Standard & Compound & Standard & Compound \\
\hline Rural 80 & $\begin{array}{c}-0.140 * * * \\
(0.029)\end{array}$ & $\begin{array}{c}-0.151 * * * \\
(0.025)\end{array}$ & $\begin{array}{c}-0.136^{* * *} \\
(0.024)\end{array}$ & - & $\begin{array}{c}-0.122 \\
(0.092)\end{array}$ & - & - & - & - \\
\hline Rural 50 & $\begin{array}{c}-0.116^{* * * *} \\
(0.029)\end{array}$ & $\begin{array}{c}-0.092 * * * \\
(0.026)\end{array}$ & $\begin{array}{c}-0.080 * * * \\
(0.025)\end{array}$ & - & - & - & $\begin{array}{c}-0.058 \\
(0.092)\end{array}$ & - & - \\
\hline Significant rural & $\begin{array}{c}-0.081 * * * \\
(0.028)\end{array}$ & $\begin{array}{c}-0.076 * * * \\
(0.024)\end{array}$ & $\begin{array}{c}-0.070 * * * \\
(0.023)\end{array}$ & - & - & - & - & - & $\begin{array}{c}-0.057 \\
(0.091)\end{array}$ \\
\hline $\begin{array}{l}\text { Log (capital stock per } \\
\text { worker) }\end{array}$ & - & $\begin{array}{c}0.271 * * * \\
(0.005) \\
\end{array}$ & $\begin{array}{c}0.305 * * * \\
(0.005) \\
\end{array}$ & $\begin{array}{c}0.311^{* * *} \\
(0.005) \\
\end{array}$ & $\begin{array}{c}-0.061 * * * \\
(0.018) \\
\end{array}$ & $\begin{array}{c}0.305 * * * \\
(0.005)\end{array}$ & $\begin{array}{l}-0.003 \\
(0.018) \\
\end{array}$ & $\begin{array}{c}0.307 * * * \\
(0.005) \\
\end{array}$ & $\begin{array}{c}-0.039 * * \\
(0.017)\end{array}$ \\
\hline Log (employees) & - & $\begin{array}{l}-0.008^{*} \\
(0.005)\end{array}$ & $\begin{array}{c}-0.007 \\
(0.004)\end{array}$ & $\begin{array}{l}-0.009^{*} \\
(0.005)\end{array}$ & $\begin{array}{c}0.034 * * \\
(0.015)\end{array}$ & $\begin{array}{c}-0.006 \\
(0.005)\end{array}$ & $\begin{array}{c}0.009 \\
(0.016)\end{array}$ & $\begin{array}{c}-0.005 \\
(0.005)\end{array}$ & $\begin{array}{c}0.011 \\
(0.015)\end{array}$ \\
\hline $\mathrm{Pt} / \mathrm{ft}$ ratio & - & $\begin{array}{c}-0.010 * * * \\
(0.001)\end{array}$ & $\begin{array}{c}-0.010 * * * \\
(0.001)\end{array}$ & $\begin{array}{c}-0.009 * * * \\
(0.001)\end{array}$ & $\begin{array}{c}-\mathbf{0 . 0 1 4} * * * \\
(0.003)\end{array}$ & $\begin{array}{c}-0.009 * * * \\
(0.001)\end{array}$ & $\begin{array}{l}-0.006 \\
(0.004)\end{array}$ & $\begin{array}{c}-0.009 * * * \\
(0.001)\end{array}$ & $\begin{array}{c}-\mathbf{0 . 0 8 7} * * * \\
(0.012)\end{array}$ \\
\hline Plants & - & $\begin{array}{c}-0.034 * * * \\
(0.008) \\
\end{array}$ & $\begin{array}{c}-0.036^{* * *} \\
(0.008)\end{array}$ & $\begin{array}{c}-0.033 * * * \\
(0.008)\end{array}$ & $\begin{array}{l}-0.041 \\
(0.029) \\
\end{array}$ & $\begin{array}{c}-0.034 * * * \\
(0.008)\end{array}$ & $\begin{array}{c}-0.028 \\
(0.030) \\
\end{array}$ & $\begin{array}{c}-0.035^{* * *} * \\
(0.008)\end{array}$ & $\begin{array}{c}-0.002 \\
(0.026) \\
\end{array}$ \\
\hline Construction & - & - & $\begin{array}{c}0.320 * * * \\
(0.032)\end{array}$ & $\begin{array}{c}0.291 * * * \\
(0.034)\end{array}$ & $\begin{array}{c}0.234 * * \\
(0.102)\end{array}$ & $\begin{array}{c}0.314 * * * \\
(0.034)\end{array}$ & $\begin{array}{c}0.033 \\
(0.103) \\
\end{array}$ & $\begin{array}{c}0.297 * * * \\
(0.034)\end{array}$ & $\begin{array}{c}0.115 \\
(0.098) \\
\end{array}$ \\
\hline Wholesale & - & - & $\begin{array}{c}0.171 * * * \\
(0.023)\end{array}$ & $\begin{array}{c}0.156 * * * \\
(0.025)\end{array}$ & $\begin{array}{c}0.127 \\
(0.075)\end{array}$ & $\begin{array}{c}0.174 * * * \\
(0.024)\end{array}$ & $\begin{array}{c}-0.032 \\
(0.077)\end{array}$ & $\begin{array}{c}0.142 * * * \\
(0.025)\end{array}$ & $\begin{array}{c}0.204 * * * \\
(0.074)\end{array}$ \\
\hline Transport & - & - & $\begin{array}{c}0.052 \\
(0.035)\end{array}$ & $\begin{array}{c}0.034 \\
(0.037)\end{array}$ & $\begin{array}{c}0.152 \\
(0.115)\end{array}$ & $\begin{array}{c}0.049 \\
(0.037)\end{array}$ & $\begin{array}{l}-0.033 \\
(0.116)\end{array}$ & $\begin{array}{c}0.033 \\
(0.037)\end{array}$ & $\begin{array}{c}0.110 \\
(0.117)\end{array}$ \\
\hline Real estate & - & - & $\begin{array}{c}0.358 * * * \\
(0.023) \\
\end{array}$ & $\begin{array}{c}0.348 * * * \\
(0.025) \\
\end{array}$ & $\begin{array}{c}0.128 \\
(0.082) \\
\end{array}$ & $\begin{array}{c}0.364 * * * \\
(0.025) \\
\end{array}$ & $\begin{array}{l}-0.010 \\
(0.081)\end{array}$ & $\begin{array}{c}0.343 * * * \\
(0.025) \\
\end{array}$ & $\begin{array}{l}0.159 * * \\
(0.076)\end{array}$ \\
\hline Manufacturing & - & - & $\begin{array}{c}0.033 \\
(0.025) \\
\end{array}$ & $\begin{array}{c}0.011 \\
(0.026) \\
\end{array}$ & $\begin{array}{c}0.163 * * \\
(0.078)\end{array}$ & $\begin{array}{c}0.023 \\
(0.025) \\
\end{array}$ & $\begin{array}{c}0.037 \\
(0.082) \\
\end{array}$ & $\begin{array}{l}-0.005 \\
(0.026)\end{array}$ & $\begin{array}{c}0.227 * * * \\
(0.080)\end{array}$ \\
\hline Hotels and catering & - & - & $\begin{array}{c}-0.828^{* * * *} \\
(0.037)\end{array}$ & $\begin{array}{c}-0.843 * * * \\
(0.039)\end{array}$ & $\begin{array}{c}0.143 \\
(0.122)\end{array}$ & $\begin{array}{c}-0.827 * * * \\
(0.039)\end{array}$ & $\begin{array}{c}0.001 \\
(0.126)\end{array}$ & $\begin{array}{c}-0.849 * * * \\
(0.037)\end{array}$ & $\begin{array}{c}0.272 * * \\
(0.116)\end{array}$ \\
\hline $\mathrm{R}^{2}$ & 0.003 & 0.200 & 0.263 & \multicolumn{2}{|c|}{0.263} & \multicolumn{2}{|c|}{0.261} & \multicolumn{2}{|c|}{0.264} \\
\hline$F$ statistic & $12.92 * * *$ & $502.53 * * *$ & $385.75 * * *$ & \multicolumn{2}{|c|}{$239.76 * * *$} & \multicolumn{2}{|c|}{$236.60 * * *$} & \multicolumn{2}{|c|}{$241.03 * * *$} \\
\hline $\begin{array}{l}\text { Test for compound } \\
\text { variables deletion }\end{array}$ & - & - & - & \multicolumn{2}{|c|}{$5.31 * * *$} & \multicolumn{2}{|c|}{0.84} & \multicolumn{2}{|c|}{$7.09 * * *$} \\
\hline
\end{tabular}

Source: ONS 
Table F: Labour productivity disparities in Rural 80, Rural 50 and Significant Rural Local Authority Districts outside of city regions, relative to the whole sample of plants outside of city regions

\begin{tabular}{|c|c|c|c|c|c|c|c|c|c|}
\hline & 1 & 2 & 3 & \multicolumn{2}{|c|}{4 (Rural 80) } & \multicolumn{2}{|c|}{5 (Rural 50) } & \multicolumn{2}{|c|}{6 (Significant rural) } \\
\hline$N$ & 1729 & 1588 & 1588 & \multicolumn{2}{|c|}{1588} & \multicolumn{2}{|c|}{1588} & \multicolumn{2}{|c|}{1588} \\
\hline & & & & Standard & Compound & Standard & Compound & Standard & Compound \\
\hline Rural 80 & $\begin{array}{l}-0.093 \\
(0.063) \\
\end{array}$ & $\begin{array}{l}-0.011 \\
(0.059)\end{array}$ & $\begin{array}{c}0.036 \\
(0.056)\end{array}$ & - & $\begin{array}{c}0.197 \\
(0.189) \\
\end{array}$ & - & - & - & - \\
\hline Rural 50 & $\begin{array}{c}0.090 \\
(0.063) \\
\end{array}$ & $\begin{array}{c}0.085 \\
(0.059)\end{array}$ & $\begin{array}{c}0.063 \\
(0.025)\end{array}$ & - & - & - & $\begin{array}{l}-0.029 \\
(0.177)\end{array}$ & - & - \\
\hline Significant rural & $\begin{array}{c}0.186 * * * \\
(0.061)\end{array}$ & $\begin{array}{c}0.162 * * * \\
(0.056)\end{array}$ & $\begin{array}{c}0.150 * * * \\
(0.023)\end{array}$ & - & - & - & - & - & $\begin{array}{l}-0.191 \\
(0.178)\end{array}$ \\
\hline $\begin{array}{l}\text { Log (capital stock per } \\
\text { worker) }\end{array}$ & - & $\begin{array}{c}0.195^{* * * *} \\
(0.015)\end{array}$ & $\begin{array}{c}0.267 * * * \\
(0.015)\end{array}$ & $\begin{array}{c}0.233 * * * \\
(0.017)\end{array}$ & $\begin{array}{l}-0.029 \\
(0.038) \\
\end{array}$ & $\begin{array}{c}0.230 * * * \\
(0.018)\end{array}$ & $\begin{array}{c}0.002 \\
(0.035) \\
\end{array}$ & $\begin{array}{c}0.212 * * * \\
(0.018)\end{array}$ & $\begin{array}{l}\mathbf{0 . 0 5 6}^{*} \\
(0.034)\end{array}$ \\
\hline Log (employees) & - & $\begin{array}{c}0.002 \\
(0.013)\end{array}$ & $\begin{array}{l}-0.005 \\
(0.013)\end{array}$ & $\begin{array}{l}-0.002 \\
(0.015)\end{array}$ & $\begin{array}{l}-0.015 \\
(0.034)\end{array}$ & $\begin{array}{l}-0.015 \\
(0.015)\end{array}$ & $\begin{array}{c}0.048 \\
(0.032)\end{array}$ & $\begin{array}{c}0.001 \\
(0.016)\end{array}$ & $\begin{array}{l}-0.019 \\
(0.029)\end{array}$ \\
\hline $\mathrm{Pt} / \mathrm{ft}$ ratio & - & $\begin{array}{c}-0.043 * * * \\
(0.006)\end{array}$ & $\begin{array}{c}-0.037 * * * \\
(0.006)\end{array}$ & $\begin{array}{c}-0.034 * * * \\
(0.006)\end{array}$ & $\begin{array}{l}-0.015 \\
(0.015)\end{array}$ & $\begin{array}{c}-0.034 * * * \\
(0.006)\end{array}$ & $\begin{array}{l}-0.022 \\
(0.018)\end{array}$ & $\begin{array}{c}-0.043 * * * \\
(0.007)\end{array}$ & $\begin{array}{c}0.015 \\
(0.011)\end{array}$ \\
\hline Plants & - & $\begin{array}{c}0.001 \\
(0.022) \\
\end{array}$ & $\begin{array}{c}0.008 \\
(0.022) \\
\end{array}$ & $\begin{array}{l}-0.006 \\
(0.024) \\
\end{array}$ & $\begin{array}{c}0.066 \\
(0.055) \\
\end{array}$ & $\begin{array}{c}0.027 \\
(0.025) \\
\end{array}$ & $\begin{array}{l}-0.081 \\
(0.052) \\
\end{array}$ & $\begin{array}{c}0.013 \\
(0.026) \\
\end{array}$ & $\begin{array}{l}-0.030 \\
(0.048) \\
\end{array}$ \\
\hline Construction & - & - & $\begin{array}{c}0.580 * * * \\
(0.086)\end{array}$ & $\begin{array}{c}0.607 * * * \\
(0.067)\end{array}$ & $\begin{array}{l}-0.123 \\
(0.220) \\
\end{array}$ & $\begin{array}{c}0.609 * * * \\
(0.099)\end{array}$ & $\begin{array}{l}-0.147 \\
(0.205) \\
\end{array}$ & $\begin{array}{c}0.507 * * * \\
(0.103)\end{array}$ & $\begin{array}{c}0.252 \\
(0.185) \\
\end{array}$ \\
\hline Wholesale & - & - & $\begin{array}{c}0.369 * * * \\
(0.062)\end{array}$ & $\begin{array}{c}0.430 * * * \\
(0.071)\end{array}$ & $\begin{array}{l}-0.266 * \\
(0.144)\end{array}$ & $\begin{array}{c}0.374 * * * \\
(0.070)\end{array}$ & $\begin{array}{l}-0.071 \\
(0.151)\end{array}$ & $\begin{array}{c}0.268 * * * \\
(0.072)\end{array}$ & $\begin{array}{c}\mathbf{0 . 3 7 5} * * * \\
(0.137)\end{array}$ \\
\hline Transport & - & - & $\begin{array}{c}0.289 * * * \\
(0.100)\end{array}$ & $\begin{array}{c}0.310 * * * \\
(0.111)\end{array}$ & $\begin{array}{c}0.106 \\
(0.261)\end{array}$ & $\begin{array}{c}0.420 * * * \\
(0.121)\end{array}$ & $\begin{array}{l}-0.415 * \\
(0.223)\end{array}$ & $\begin{array}{l}0.261 * * \\
(0.117)\end{array}$ & $\begin{array}{c}0.096 \\
(0.222)\end{array}$ \\
\hline Real estate & - & - & $\begin{array}{c}0.497 * * * \\
(0.072)\end{array}$ & $\begin{array}{c}0.529 * * * \\
(0.081) \\
\end{array}$ & $\begin{array}{c}0.124 \\
(0.174) \\
\end{array}$ & $\begin{array}{c}0.517 * * * \\
(0.081)\end{array}$ & $\begin{array}{l}-0.065 \\
(0.177) \\
\end{array}$ & $\begin{array}{c}0.390 * * * \\
(0.086) \\
\end{array}$ & $\begin{array}{c}0.371 * * \\
(0.155) \\
\end{array}$ \\
\hline Manufacturing & - & - & $\begin{array}{c}0.400 * * * \\
(0.064)\end{array}$ & $\begin{array}{c}0.415^{* * *} \\
(0.074)\end{array}$ & $\begin{array}{c}0.119 \\
(0.148) \\
\end{array}$ & $\begin{array}{c}0.406 * * * \\
(0.072)\end{array}$ & $\begin{array}{l}-0.118 \\
(0.159) \\
\end{array}$ & $\begin{array}{c}0.341 * * * \\
(0.074)\end{array}$ & $\begin{array}{c}0.181 \\
(0.144) \\
\end{array}$ \\
\hline Hotels and catering & - & - & $\begin{array}{c}-0.541 * * * \\
(0.094)\end{array}$ & $\begin{array}{c}-0.605 * * * \\
(0.113)\end{array}$ & $\begin{array}{c}0.148 \\
(0.203)\end{array}$ & $\begin{array}{c}-0.551 * * * \\
(0.103)\end{array}$ & $\begin{array}{l}-0.019 \\
(0.246)\end{array}$ & $\begin{array}{c}-0.508 * * * \\
(0.106)\end{array}$ & $\begin{array}{l}-0.240 \\
(0.224)\end{array}$ \\
\hline $\mathrm{R}^{2}$ & 0.013 & 0.168 & 0.255 & \multicolumn{2}{|c|}{0.255} & \multicolumn{2}{|c|}{0.255} & \multicolumn{2}{|c|}{0.263} \\
\hline$F$ statistic & $7.26^{* * *}$ & $45.42 * * *$ & $41.45 * * *$ & \multicolumn{2}{|c|}{$25.53 * * *$} & \multicolumn{2}{|c|}{$25.54 * * *$} & \multicolumn{2}{|c|}{$26.55 * * *$} \\
\hline $\begin{array}{l}\text { Test for compound } \\
\text { variables deletion }\end{array}$ & - & - & - & \multicolumn{2}{|c|}{0.76} & \multicolumn{2}{|c|}{0.77} & \multicolumn{2}{|c|}{$2.22 * *$} \\
\hline
\end{tabular}

Source: ONS 
Table G: productivity profiles of lagging districts compared to Rural 80 districts.

\begin{tabular}{|c|c|c|c|c|c|}
\hline & 1 & 2 & 3 & \multicolumn{2}{|c|}{4} \\
\hline$n$ & 2554 & 2341 & 2341 & \multicolumn{2}{|c|}{2341} \\
\hline & & & & Standard & Compound \\
\hline Lagging district & $\begin{array}{c}-0.130 * * * \\
(0.037)\end{array}$ & $\begin{array}{c}-0.088 * * * \\
(0.034)\end{array}$ & $\begin{array}{c}-0.077 * * \\
(0.033)\end{array}$ & - & $\begin{array}{c}-0.108 \\
(0.125)\end{array}$ \\
\hline $\begin{array}{l}\text { Log (capital } \\
\text { stock per } \\
\text { worker) }\end{array}$ & - & $\begin{array}{c}0.209 * * * \\
(0.012)\end{array}$ & $\begin{array}{c}0.243 * * * \\
(0.012)\end{array}$ & $\begin{array}{c}0.246 * * * \\
(0.016)\end{array}$ & $\begin{array}{c}-0.018 \\
(0.025)\end{array}$ \\
\hline Log(employees) & - & $\begin{array}{c}0.010 \\
(0.011)\end{array}$ & $\begin{array}{c}0.012 \\
(0.011)\end{array}$ & $\begin{array}{c}0.002 \\
(0.014)\end{array}$ & $\begin{array}{c}0.022 \\
(0.022)\end{array}$ \\
\hline $\mathrm{Pt} / \mathrm{ft}$ ratio & - & $\begin{array}{c}-0.027 * * * \\
(0.003)\end{array}$ & $\begin{array}{c}-0.025^{* * *} \\
(0.003)\end{array}$ & $\begin{array}{c}-0.022 * * * \\
(0.003)\end{array}$ & $\begin{array}{c}-\mathbf{- 0 . 0 4 3} * * * \\
(0.010)\end{array}$ \\
\hline Plants & - & $\begin{array}{l}-0.038^{*} \\
(0.020) \\
\end{array}$ & $\begin{array}{c}-0.044 * * \\
(0.020)\end{array}$ & $\begin{array}{l}-0.049 * \\
(0.027) \\
\end{array}$ & $\begin{array}{c}0.012 \\
(0.039) \\
\end{array}$ \\
\hline Construction & - & - & $\begin{array}{c}0.494 * * * \\
(0.069)\end{array}$ & $\begin{array}{c}0.478 * * * \\
(0.093)\end{array}$ & $\begin{array}{c}0.005 \\
(0.139)\end{array}$ \\
\hline Wholesale & - & - & $\begin{array}{c}0.241 * * * \\
(0.051)\end{array}$ & $\begin{array}{c}0.230 * * * \\
(0.066)\end{array}$ & $\begin{array}{c}0.017 \\
(0.103)\end{array}$ \\
\hline Transport & - & - & $\begin{array}{c}0.199 * * * \\
(0.075)\end{array}$ & $\begin{array}{c}0.111 \\
(0.104)\end{array}$ & $\begin{array}{c}0.157 \\
(0.151)\end{array}$ \\
\hline Real estate & - & - & $\begin{array}{c}0.455 * * * \\
(0.057)\end{array}$ & $\begin{array}{c}0.483 * * * \\
(0.071)\end{array}$ & $\begin{array}{c}-0.092 * * * \\
(0.019)\end{array}$ \\
\hline Manufacturing & - & - & $\begin{array}{c}0.506 * * * \\
(0.053)\end{array}$ & $\begin{array}{c}0.155^{* *} \\
(0.069)\end{array}$ & $\begin{array}{c}0.092 \\
(0.107)\end{array}$ \\
\hline $\begin{array}{l}\text { Hotels and } \\
\text { catering }\end{array}$ & - & - & $\begin{array}{c}-0.631 * * * \\
(0.079)\end{array}$ & $\begin{array}{c}-0.710 * * * \\
(0.104)\end{array}$ & $\begin{array}{c}0.221 \\
(0.160)\end{array}$ \\
\hline $\mathrm{R}^{2}$ & 0.005 & 0.185 & 0.259 & \multicolumn{2}{|c|}{0.267} \\
\hline$F$ statistic & $12.25 * * *$ & $105.99 * * *$ & $74.08 * * *$ & \multicolumn{2}{|c|}{$40.30 * * *$} \\
\hline $\begin{array}{l}\text { Test for } \\
\text { compound } \\
\text { variables } \\
\text { deletion }\end{array}$ & - & - & - & \multicolumn{2}{|c|}{$2.86 * * *$} \\
\hline
\end{tabular}

Source: ONS 
Table H: productivity profiles of lagging districts compared to Rural 50 districts.

\begin{tabular}{|c|c|c|c|c|c|}
\hline & 1 & 2 & 3 & \multicolumn{2}{|c|}{4} \\
\hline$n$ & 2627 & 2409 & 2409 & \multicolumn{2}{|c|}{2409} \\
\hline & & & & Standard & Compound \\
\hline Lagging district & $\begin{array}{c}-0.136 * * * \\
(0.037)\end{array}$ & $\begin{array}{c}-0.116^{* * * *} \\
(0.033)\end{array}$ & $\begin{array}{c}-0.099 * * * \\
(0.032)\end{array}$ & - & $\begin{array}{c}0.013 \\
(0.123)\end{array}$ \\
\hline $\begin{array}{l}\text { Log (capital } \\
\text { stock per } \\
\text { worker) }\end{array}$ & - & $\begin{array}{c}0.241 * * * \\
(0.012)\end{array}$ & $\begin{array}{c}0.273 * * * \\
(0.012)\end{array}$ & $\begin{array}{c}0.297 * * * \\
(0.015)\end{array}$ & $\begin{array}{c}-0.069 * * * \\
(0.024)\end{array}$ \\
\hline Log(employees) & - & $\begin{array}{l}0.018 * \\
(0.010)\end{array}$ & $\begin{array}{c}0.015 \\
(0.010)\end{array}$ & $\begin{array}{c}0.009 \\
(0.013)\end{array}$ & $\begin{array}{c}0.015 \\
(0.021)\end{array}$ \\
\hline $\mathrm{Pt} / \mathrm{ft}$ ratio & - & $\begin{array}{c}-0.024 * * * \\
(0.004)\end{array}$ & $\begin{array}{c}-0.022 * * * \\
(0.003)\end{array}$ & $\begin{array}{c}-0.015^{* * * *} \\
(0.004)\end{array}$ & $\begin{array}{c}-0.050 * * * \\
(0.011)\end{array}$ \\
\hline Plants & - & $\begin{array}{l}-0.048^{*} \\
(0.018)\end{array}$ & $\begin{array}{c}-0.048 * * * \\
(0.018)\end{array}$ & $\begin{array}{c}-0.054 * * \\
(0.024)\end{array}$ & $\begin{array}{c}0.016 \\
(0.037)\end{array}$ \\
\hline Construction & - & - & $\begin{array}{c}0.467 * * * \\
(0.067)\end{array}$ & $\begin{array}{c}0.426 * * * \\
(0.088)\end{array}$ & $\begin{array}{c}0.057 \\
(0.135)\end{array}$ \\
\hline Wholesale & - & - & $\begin{array}{c}0.223 * * * \\
(0.050)\end{array}$ & $\begin{array}{c}0.201 * * * \\
(0.064)\end{array}$ & $\begin{array}{c}0.045 \\
(0.102)\end{array}$ \\
\hline Transport & - & - & $\begin{array}{l}0.134^{*} \\
(0.074)\end{array}$ & $\begin{array}{c}0.001 \\
(0.100)\end{array}$ & $\begin{array}{l}0.268 * \\
(0.149)\end{array}$ \\
\hline Real estate & - & - & $\begin{array}{c}0.386 * * * \\
(0.055)\end{array}$ & $\begin{array}{c}0.376 * * * \\
(0.068)\end{array}$ & $\begin{array}{c}0.016 \\
(0.117)\end{array}$ \\
\hline Manufacturing & - & - & $\begin{array}{c}0.183 * * * \\
(0.052)\end{array}$ & $\begin{array}{l}0.124^{*} \\
(0.069)\end{array}$ & $\begin{array}{c}0.123 \\
(0.106)\end{array}$ \\
\hline $\begin{array}{l}\text { Hotels and } \\
\text { catering }\end{array}$ & - & - & $\begin{array}{c}-0.692 * * * \\
(0.080)\end{array}$ & $\begin{array}{c}-0.818 * * * \\
(0.107)\end{array}$ & $\begin{array}{c}0.328 * * \\
(0.162)\end{array}$ \\
\hline $\mathrm{R}^{2}$ & 0.005 & 0.205 & 0.274 & \multicolumn{2}{|c|}{0.284} \\
\hline$F$ statistic & $13.14 * * *$ & $123.83 * * *$ & $82.21 * * *$ & \multicolumn{2}{|c|}{$44.99 * * *$} \\
\hline $\begin{array}{l}\text { Test for } \\
\text { compound } \\
\text { variables } \\
\text { deletion }\end{array}$ & - & - & - & \multicolumn{2}{|c|}{$3.79 * * *$} \\
\hline
\end{tabular}

Source: ONS 
Table I: productivity profiles of lagging districts compared to Significant Rural districts.

\begin{tabular}{|c|c|c|c|c|c|}
\hline & 1 & 2 & 3 & \multicolumn{2}{|c|}{4} \\
\hline$n$ & 3161 & 2909 & 2909 & \multicolumn{2}{|c|}{2909} \\
\hline & & & & Standard & Compound \\
\hline Lagging district & $\begin{array}{c}-0.176 * * * \\
(0.037)\end{array}$ & $\begin{array}{c}-0.129 * * * \\
(0.033)\end{array}$ & $\begin{array}{c}-0.107 * * * \\
(0.032)\end{array}$ & - & $\begin{array}{c}0.080 \\
(0.126)\end{array}$ \\
\hline $\begin{array}{l}\text { Log (capital } \\
\text { stock per } \\
\text { worker) } \\
\end{array}$ & - & $\begin{array}{c}0.226 * * * \\
(0.011)\end{array}$ & $\begin{array}{c}0.262 * * * \\
(0.012)\end{array}$ & $\begin{array}{c}0.277 * * * \\
(0.014)\end{array}$ & $\begin{array}{c}-0.049 * * \\
(0.025)\end{array}$ \\
\hline Log(employees) & - & $\begin{array}{c}0.006 \\
(0.010)\end{array}$ & $\begin{array}{c}0.011 \\
(0.010)\end{array}$ & $\begin{array}{c}0.005 \\
(0.012)\end{array}$ & $\begin{array}{c}0.019 \\
(0.021)\end{array}$ \\
\hline $\mathrm{Pt} / \mathrm{ft}$ ratio & - & $\begin{array}{c}-0.068 * * * \\
(0.006)\end{array}$ & $\begin{array}{c}-0.056^{* * * *} \\
(0.006)\end{array}$ & $\begin{array}{c}-0.051 * * * \\
(0.007)\end{array}$ & $\begin{array}{l}-0.014 \\
(0.013)\end{array}$ \\
\hline Plants & - & $\begin{array}{l}-0.032^{*} \\
(0.017)\end{array}$ & $\begin{array}{c}-0.040 * * \\
(0.017)\end{array}$ & $\begin{array}{l}-0.040^{*} \\
(0.021)\end{array}$ & $\begin{array}{c}0.003 \\
(0.036)\end{array}$ \\
\hline Construction & - & - & $\begin{array}{c}0.507 * * * \\
(0.063)\end{array}$ & $\begin{array}{c}0.518 * * * \\
(0.078)\end{array}$ & $\begin{array}{l}-0.034 \\
(0.133)\end{array}$ \\
\hline Wholesale & - & - & $\begin{array}{c}0.383 * * * \\
(0.049)\end{array}$ & $\begin{array}{c}0.452^{* * *} * \\
(0.060)\end{array}$ & $\begin{array}{c}-0.205 * * \\
(0.103)\end{array}$ \\
\hline Transport & - & - & $\begin{array}{c}0.264 * * * \\
(0.074)\end{array}$ & $\begin{array}{c}0.239 * * \\
(0.098)\end{array}$ & $\begin{array}{c}0.030 \\
(0.152)\end{array}$ \\
\hline Real estate & - & - & $\begin{array}{c}0.525 * * \\
(0.053)\end{array}$ & $\begin{array}{c}0.579 * * * \\
(0.062)\end{array}$ & $\begin{array}{l}-0.188 \\
(0.118)\end{array}$ \\
\hline Manufacturing & - & - & $\begin{array}{c}0.294 * * * \\
(0.051)\end{array}$ & $\begin{array}{c}0.321 * * * \\
(0.064)\end{array}$ & $\begin{array}{l}-0.074 \\
(0.107)\end{array}$ \\
\hline $\begin{array}{l}\text { Hotels and } \\
\text { catering }\end{array}$ & - & - & $\begin{array}{c}-0.570 * * * \\
(0.076)\end{array}$ & $\begin{array}{c}-0.606 * * * \\
(0.094)\end{array}$ & $\begin{array}{c}0.116 \\
(0.160)\end{array}$ \\
\hline $\mathrm{R}^{2}$ & 0.007 & 0.191 & 0.264 & \multicolumn{2}{|c|}{0.267} \\
\hline$F$ statistic & $22.81 * * *$ & $136.69 * * *$ & $94.40 * * *$ & \multicolumn{2}{|c|}{$50.07 * * *$} \\
\hline $\begin{array}{l}\text { Test for } \\
\text { compound } \\
\text { variables } \\
\text { deletion }\end{array}$ & - & - & - & \multicolumn{2}{|c|}{$2.12 * *$} \\
\hline
\end{tabular}

Source: ONS 
Table J: Chi ${ }^{2}$ tests of labour productivity in city regions and lagging districts

\begin{tabular}{lccc} 
& Mean & $\begin{array}{c}\text { Standard } \\
\text { deviation }\end{array}$ & $\operatorname{Pr}(|\mathrm{T}|>|\mathrm{t}|)$ \\
\hline City region & 3.306 & 1.067 & 0.000 \\
Not city region & 3.143 & 0.928 & \multirow{2}{*}{0.000} \\
\hline Not lagging district & 3.307 & 1.067 & \multirow{2}{*}{0.000} \\
Lagging district & 3.093 & 0.907 & \multirow{2}{*}{0.001} \\
\hline City region: not lagging district & 3.318 & 1.076 & \\
City region: lagging district & 3.144 & 0.955 & 0.958 \\
\hline Not city region: not lagging district & 3.188 & 0.835 & \\
Not city region: lagging district & 3.024 & &
\end{tabular}

Source: ONS 
Figure 1 - the default rural definition pertaining to England and Wales

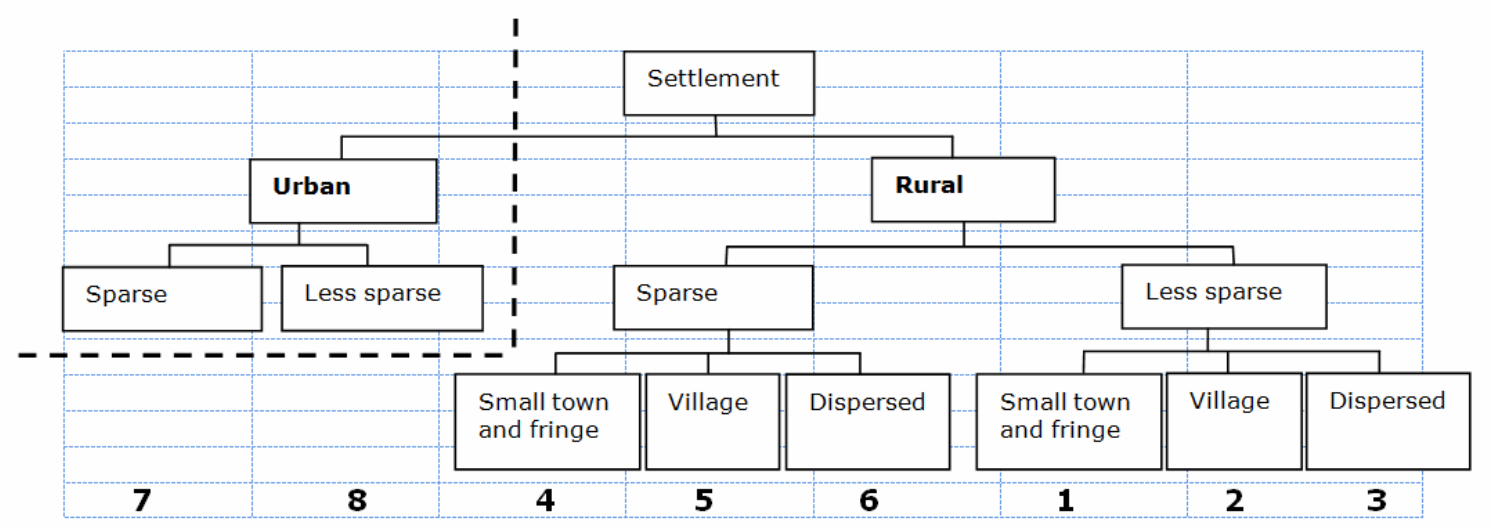

Source: adapted from Defra, (2005a) 
Figure 2 - Defra Classification of Local Authority Districts (LADs)

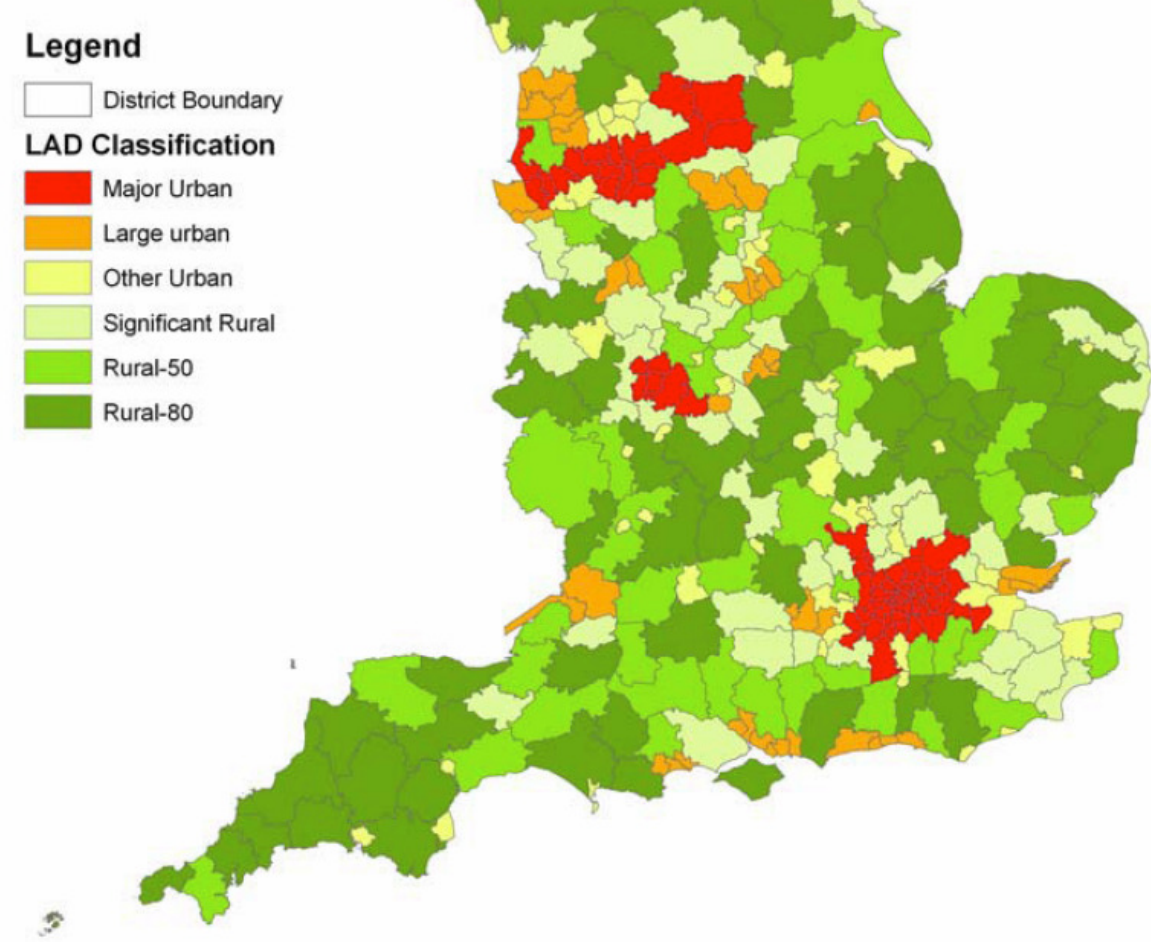

Source: Defra (2005a) Annex Two 
Figure 3 - city-regions by local authority district

\section{LAD Classification}

A- District is not in a CR

B. District is in one CR only and is not a node

C. District is in one $C R$ and is a nade in that $C R$

D- District is in two or more CRs but is not a node

E- District is a node in one $C R$ and is also in another CR (it is not a node in the second)

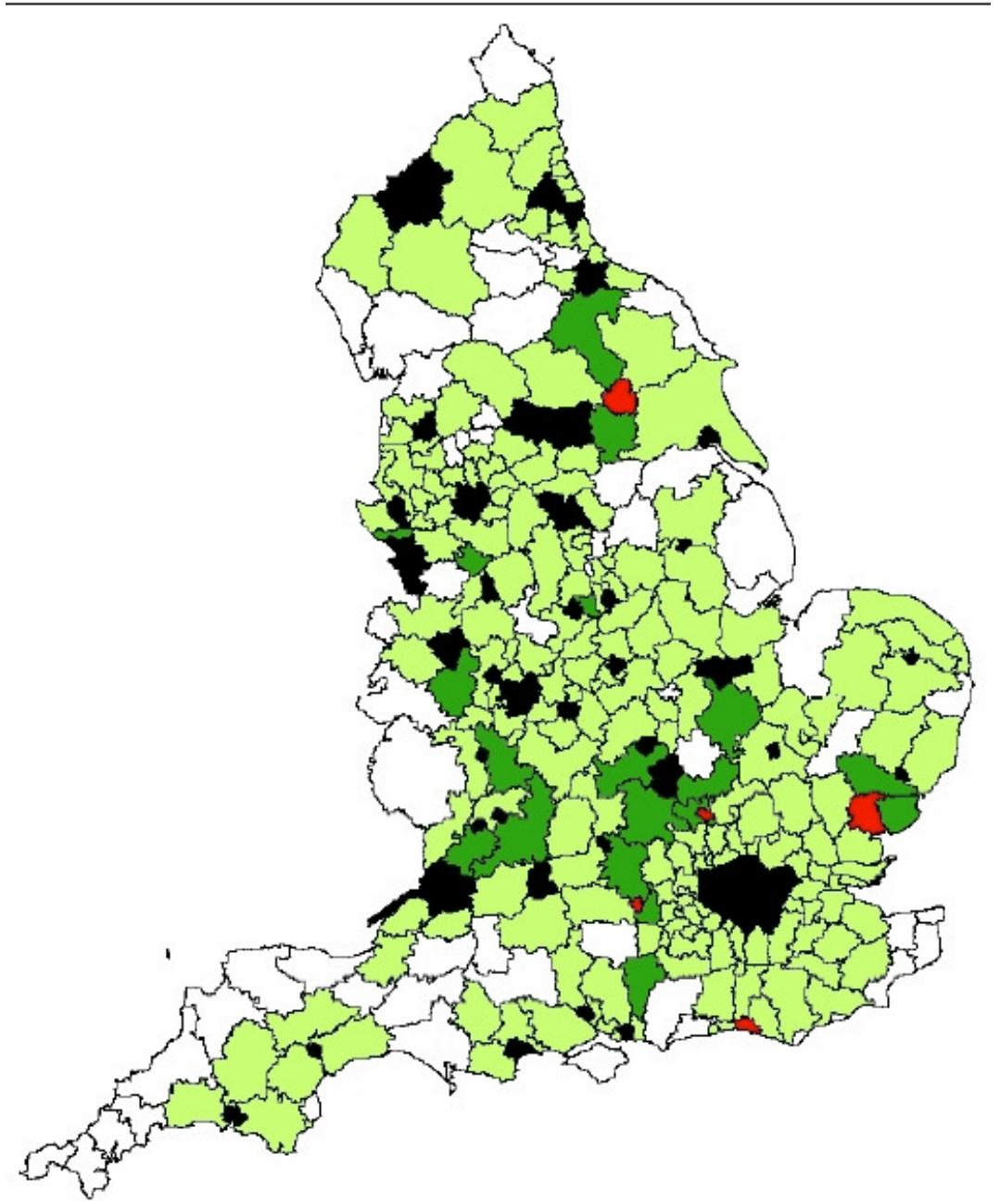

Source: SQW and Cambridge Econometrics (2006) 
Figure 4: Defra's low productivity districts

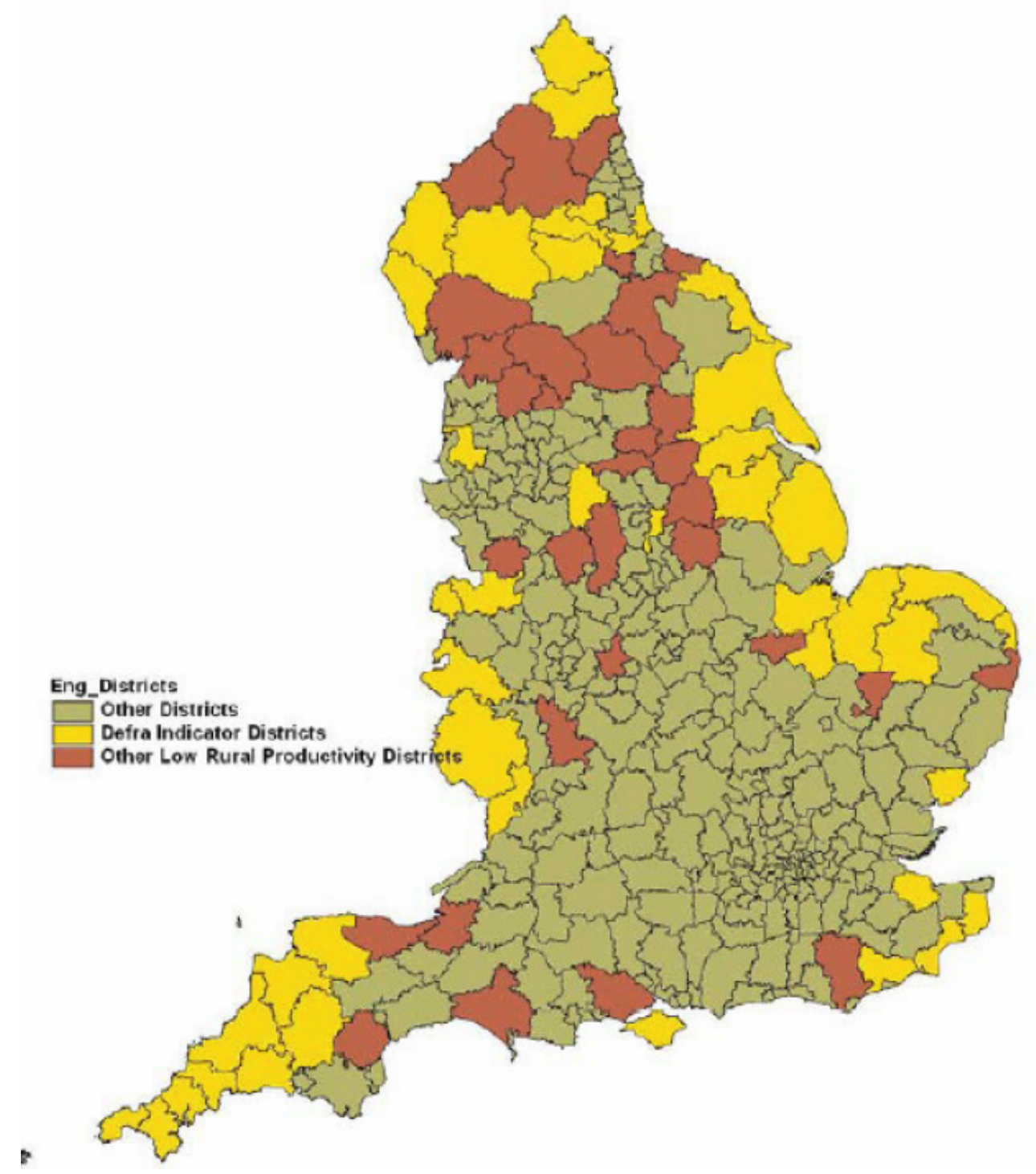

Source: DEFRA (2006) cited in Annibal and Boyle (2007) 
Figure 5: Low productivity rural districts and city-regions

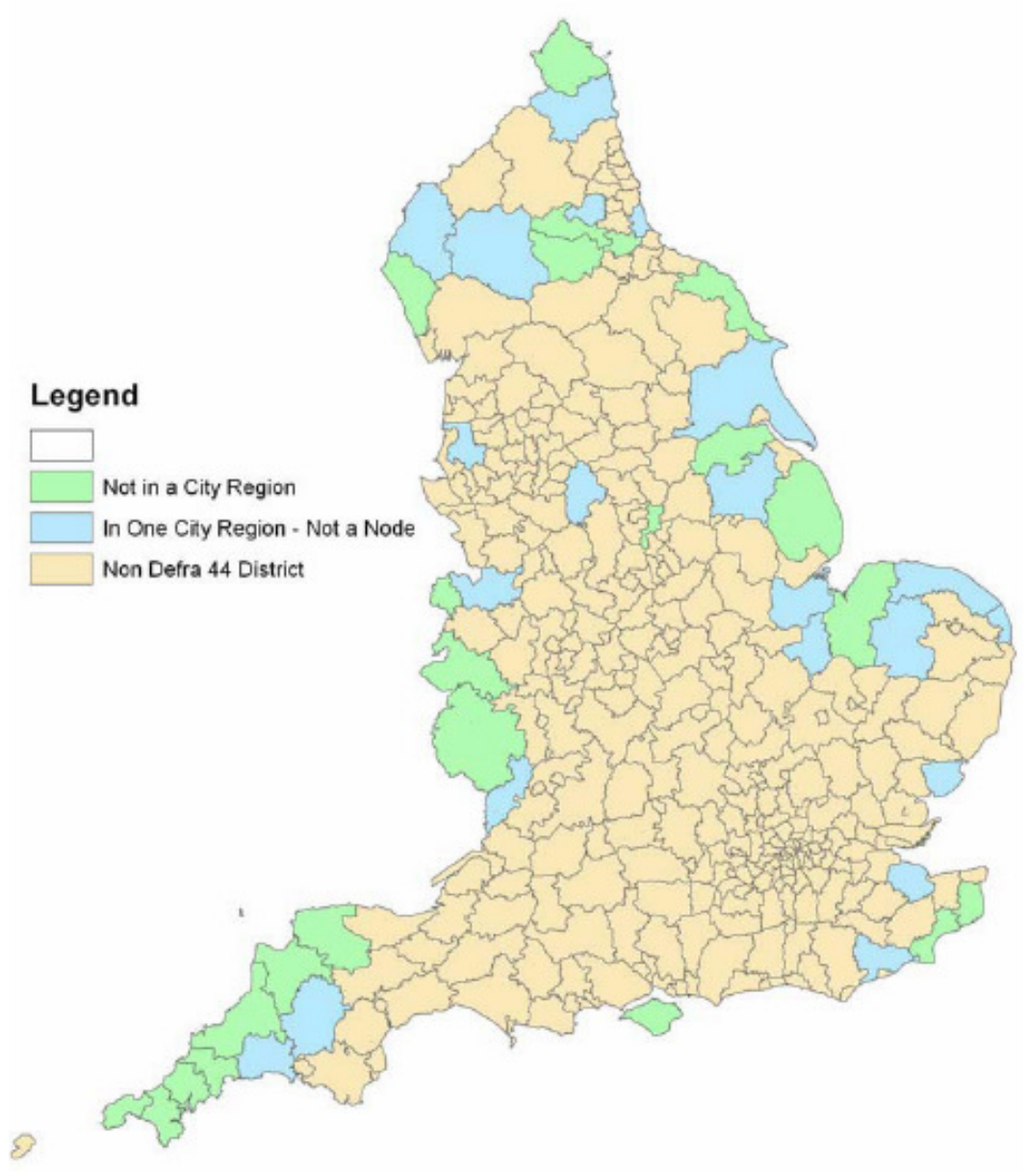

Source: Annibal and Boyle (2007) 